\title{
Mapping the past, present and future research landscape of paternal effects
}

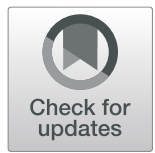

\author{
Joanna Rutkowska ${ }^{1,2^{*}}$, Malgorzata Lagisz ${ }^{2}$ (D) Russell Bonduriansky ${ }^{2}$ (D) and Shinichi Nakagawa ${ }^{2}$ (D)
}

\begin{abstract}
Background: Although in all sexually reproducing organisms an individual has a mother and a father, non-genetic inheritance has been predominantly studied in mothers. Paternal effects have been far less frequently studied, until recently. In the last 5 years, research on environmentally induced paternal effects has grown rapidly in the number of publications and diversity of topics. Here, we provide an overview of this field using synthesis of evidence (systematic map) and influence (bibliometric analyses).

Results: We find that motivations for studies into paternal effects are diverse. For example, from the ecological and evolutionary perspective, paternal effects are of interest as facilitators of response to environmental change and mediators of extended heredity. Medical researchers track how paternal pre-fertilization exposures to factors, such as diet or trauma, influence offspring health. Toxicologists look at the effects of toxins. We compare how these three research guilds design experiments in relation to objects of their studies: fathers, mothers and offspring. We highlight examples of research gaps, which, in turn, lead to future avenues of research.

Conclusions: The literature on paternal effects is large and disparate. Our study helps in fostering connections between areas of knowledge that develop in parallel, but which could benefit from the lateral transfer of concepts and methods.
\end{abstract}

Keywords: Research weaving, Systematic review, Meta-analysis, Parental effects, Transgenerational effects, Transgenerational plasticity

\section{Background}

What does ocean acidification have in common with the Dutch famine? They both exert effects that can be nongenetically transmitted from the fathers to their offspring. Publications on such paternal effects (for definitions and nuances, see Table 1) are increasing in number and diversity, with research coming from evolutionary biology [22, 23], medicine [5, 11, 24] and toxicology [25]. Research on paternal effects carried out within those disciplines pursues different goals. For example, evolutionary ecologists seek to

\footnotetext{
* Correspondence: joanna.rutkowska@uj.edu.pl

'Institute of Environmental Sciences, Faculty of Biology, Jagiellonian University, Kraków, Poland

2Evolution \& Ecology Research Centre, School of Biological, Earth and Environmental Sciences, BEES, The University of New South Wales, Sydney, Australia
}

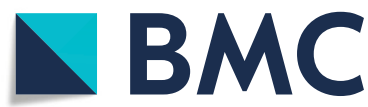

(c) The Author(s). 2020 Open Access This article is licensed under a Creative Commons Attribution 4.0 International License, which permits use, sharing, adaptation, distribution and reproduction in any medium or format, as long as you give appropriate credit to the original author(s) and the source, provide a link to the Creative Commons licence, and indicate if changes were made. The images or other third party material in this article are included in the article's Creative Commons licence, unless indicated otherwise in a credit line to the material. If material is not included in the article's Creative Commons licence and your intended use is not permitted by statutory regulation or exceeds the permitted use, you will need to obtain permission directly from the copyright holder. To view a copy of this licence, visit http://creativecommons.org/licenses/by/4.0/. The Creative Commons Public Domain Dedication waiver (http://creativecommons.org/publicdomain/zero/1.0/) applies to the data made available in this article, unless otherwise stated in a credit line to the data.

understand how paternal effects contribute to heritable variation, how they are influenced by the ambient environment and what role they play in evolution. By contrast, medical and health researchers seek to understand how male health and lifestyle can influence the health of descendants. In each of these disciplines, research is carried out using somewhat different tools and approaches. Crossfertilization between these disciplines could be very valuable but has been hampered by the use of distinct terminologies and publication outlets.

While several thorough and influential reviews of paternal effect research have been published (e.g. $[6,25])$, they are focused on a specific type of manipulation eliciting the non-genetic inheritance, or the proximate mechanisms mediating the phenomenon, rarely covering the entire field of paternal effects research. Meta-research (i.e. research on 
Table 1 Definitions

\section{a) Disambiguation}

Paternal effect is a broad term encompassing (i) transgenerational plasticity where the phenotypic change in offspring occurs in response to the paternal environment or phenotype [1], (ii) indirect genetic effects IGEs where alleles expressed in the father affect the development of his offspring [2] and (iii) effects of spontaneous or stochastic variation in non-genetic factors such as epigenetic marks (i.e. variation that is not induced consistently by particular environmental factor). In the current review, we focus on transgenerational plasticity.

\section{b) Meaning of paternal effect across the research fields}

Evolutionary biologists delineate paternal effects most broadly [3]. In this field, a paternal effect reflects the influence of paternal environment or age on offspring traits and can be mediated by paternal care or by factors (such as RNA or proteins) in sperm of seminal fluid. The medical definition usually does not encompass effects transmitted via paternal care [4]. Researchers interested in inheritance of metabolic diseases narrow the definition further into 'epigenetic programming' [5] and do not consider age as a part of paternal effects. In terms of the proximate mechanisms, the definitions encompass sperm-borne mechanisms, such as DNA methylation, chromatin alterations and non-coding RNAs [3-6]. In addition, evolutionary perspective is likely to consider mechanisms acting via ejaculate-borne agents, e.g. RNA and proteins, reviewed by [7].

\section{c) The term 'paternal effect' in other contexts}

Identity: the term is sometimes used to account for paternal identity in statistical models, either in a full-factorial experiment [8] or in studies designed to estimate genetic parameters of sires in animal breeding [9].

Genetics: the term could mean an effect that arises due to the male-specific sex chromosome [10]. The term can denote inheritance of genes through the patriline which exhibits parent-of-origin expression [4], called also 'epivariation' [11]. 'Paternal effect locus' is a locus whose expression in a male influences the development of his offspring (i.e. an IGE). Recently, it is also referred to as 'male genetic quality', related to inbreeding [12].

Symbionts/parasites: although not commonplace, there is evidence that males may transmit symbionts [13] and parasites to their offspring. For instance, males with Wolbachia cause embryonic lethality [14]. There is also evidence for paternal mitochondria leakage in animals and humans [15]; these phenomena would be classified as male-specific genetic inheritance, yet to our knowledge have so far not been named 'paternal effect'.

Assisted reproduction: in assisted reproduction treatment, the term 'early paternal effect' refers to failure at the initial stages of the procedure, resulting in zygote malformation, while 'late paternal effect' refers to the failure at the stage of implantation [16].

\section{d) Interface of epigenetics and genetics}

Research into paternal effects sheds light on interrelations between different forms of inheritance and their interactions with the environment. First, epigenotype controls the expression of the genotype, while both the genotype and the environment shape the epigenotype [17]. Second, environmentally induced epigenetic processes can promote genetic mutations [18]. Third, factors with mutagenic or cancerogenic effects can also exert epigenetic effects. Exposure to such factors (e.g. smoking) does not allow disentangling the epigenetic effect per se. Finally, classification of effects due to male age is ambiguous. Older males might accumulate effects of lifetime exposure to various environmental [19] and other factors (e.g. exercise). However, older males also have higher numbers of de novo mutations in germline DNA (reviewed, e.g. by [20]) and altered DNA methylation patterns, known as 'epigenetic clock' [21], which places age at the interface of genetic and non-genetic factors.

research) could therefore help to identify gaps, biases and clusters in order to facilitate future investigation of paternal effects [26, 27]. Our aim is to construct a systematic and meta-scientific overview of paternal effects research across all relevant fields. Our methodology (Fig. 1) is informed by 'research weaving' [29] encompassing synthesis of evidence (systematic map) and influence (bibliometric analyses). A systematic map uses a methodology of literature search similar to that of a systematic review [30, 31]. A systematic map can have a broad scope, allowing for heterogeneity of taxonomic groups and experimental methods, which are usually not consistent across fields. Such a map could include both empirical and non-empirical studies. Adding bibliometric analyses to a systematic map allows assessing networks of ideas and scientists. We use this map to identify research clusters, as well as collaborations that could benefit from cross-disciplinary fertilization of ideas and approaches, particularly between medical and evolutionaryecological research.

To achieve this goal, we map the past, present and future of the parental effect research. First, we examine temporal and topical trends in the literature and also, via bibliometric analysis, identify three 'guilds' (clusters of studies from different research domains). Second, we take a tour of the rather complex experimental landscape, by seeing how the three different guilds design experiments in relation to three family members: fathers, mothers and their children. Third, we highlight three examples of research gaps, which, in turn, lead to future avenues of research. Finally, we offer six considerations for improving future experimental work by integrating insights from our map.

\section{Results and discussion}

Characterizing temporal, topical and bibliometric patterns An emerging field of meta-research has recently taught us that, to improve our research practice, we should learn from 'history' [29]. To learn the history of a field, our first step is to examine and characterize the trends and patterns in the literature.

\section{Temporal trends in paternal effect research}

Research publications in this field have doubled in number in the last 5 years (Fig. 2). An increasing volume of empirical literature represents the diversity of paternal exposures, with the most pronounced growth in studies 
a

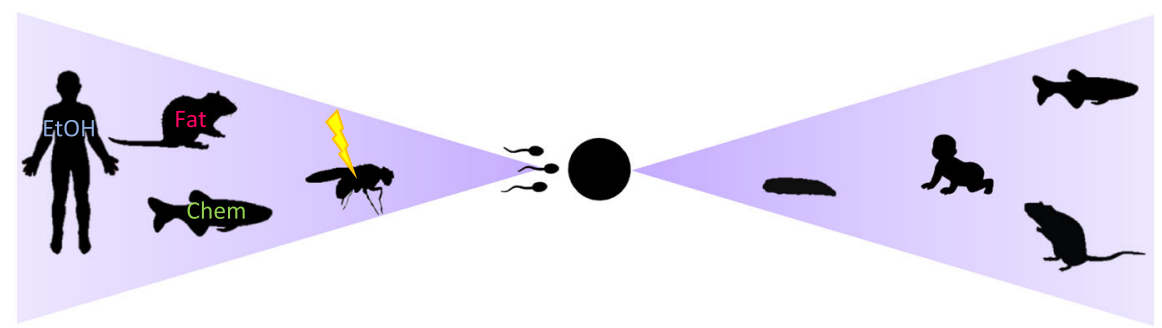

b

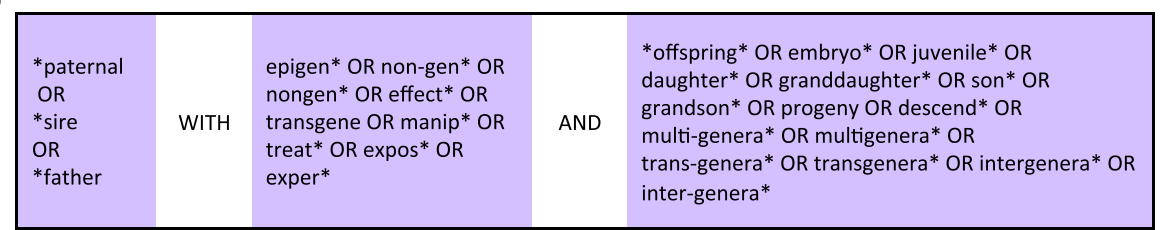

C
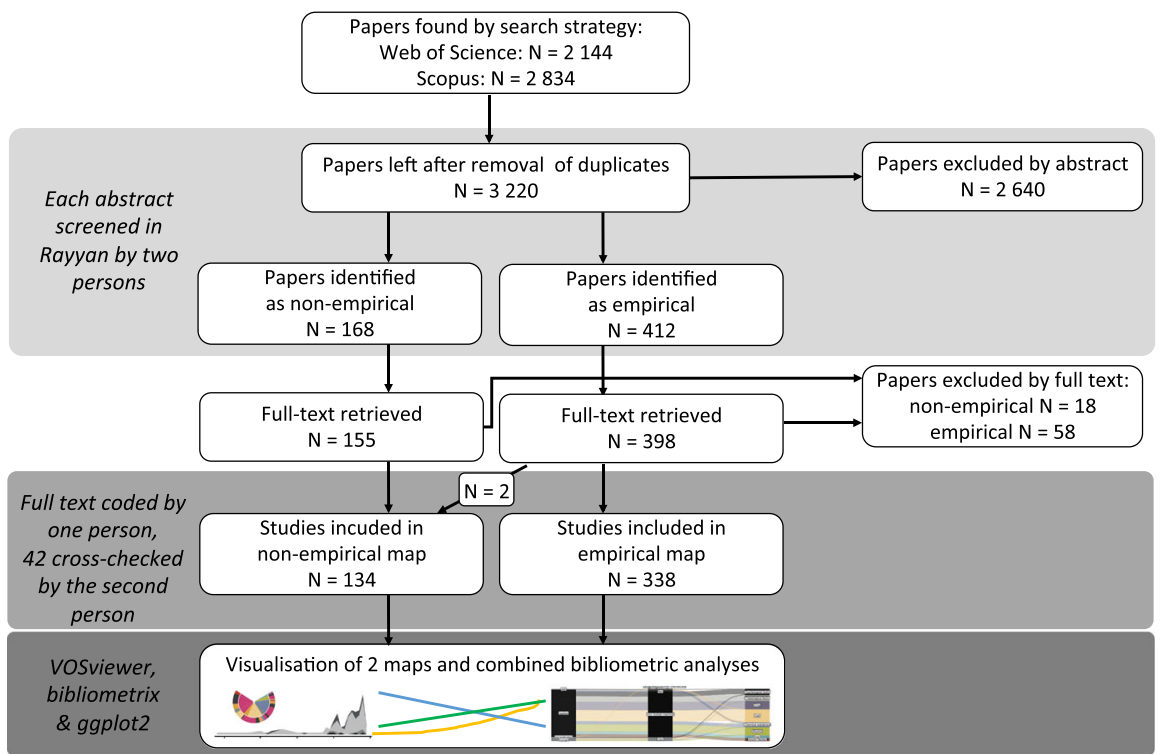

Fig. 1 Methods used to create the systematic evidence map of paternal effects research field. a The map is based on the published papers on environmentally induced non-genetic paternal germline and semen effects. b Keywords used to search the Scopus and Web of Science databases. c PRISMA diagram [28] outlining the procedure applied after the literature search

investigating trans-generational effects of diet and of psychological factors (Fig. 2a). The growth of empirical evidence is accompanied by the parallel growth of nonempirical papers (Fig. 2b), mostly narrative reviews, with notable scarcity of theoretical papers and systematic reviews (and derivatives [40]). From the secondary literature, we can conclude that the most attention in the field is currently directed towards common health outcomes of paternal exposures: metabolic disorders and detrimental effects of drugs and toxins. Existing reviews often present relatively narrow focus perspective: (1) researchers consider proximate mechanisms of paternal effects to a specific type of exposure, or (2) they associate specific exposure with particular offspring outcomes (Fig. 2c).

\section{Three guilds in the paternal effect literature}

As bibliometric clustering algorithm indicated, empirical research in the field of paternal effects has been carried out by three separate guilds, which we call toxicologists, medical scientists and ecology and evolution (eco-evo) researchers (Fig. 3a). Toxicologists maintain the most distinct research guild (Fig. 3b). They typically describe the effects of environmental factors that have negative effects both on the paternal and offspring generations. In this research cluster, there is a substantial share of observational (with a matched control group) studies on humans, while rodents are used as model species in experimental studies (Fig. 4a). We have found that this cluster is the oldest among the three (see Additional File: Fig. S1) and that 


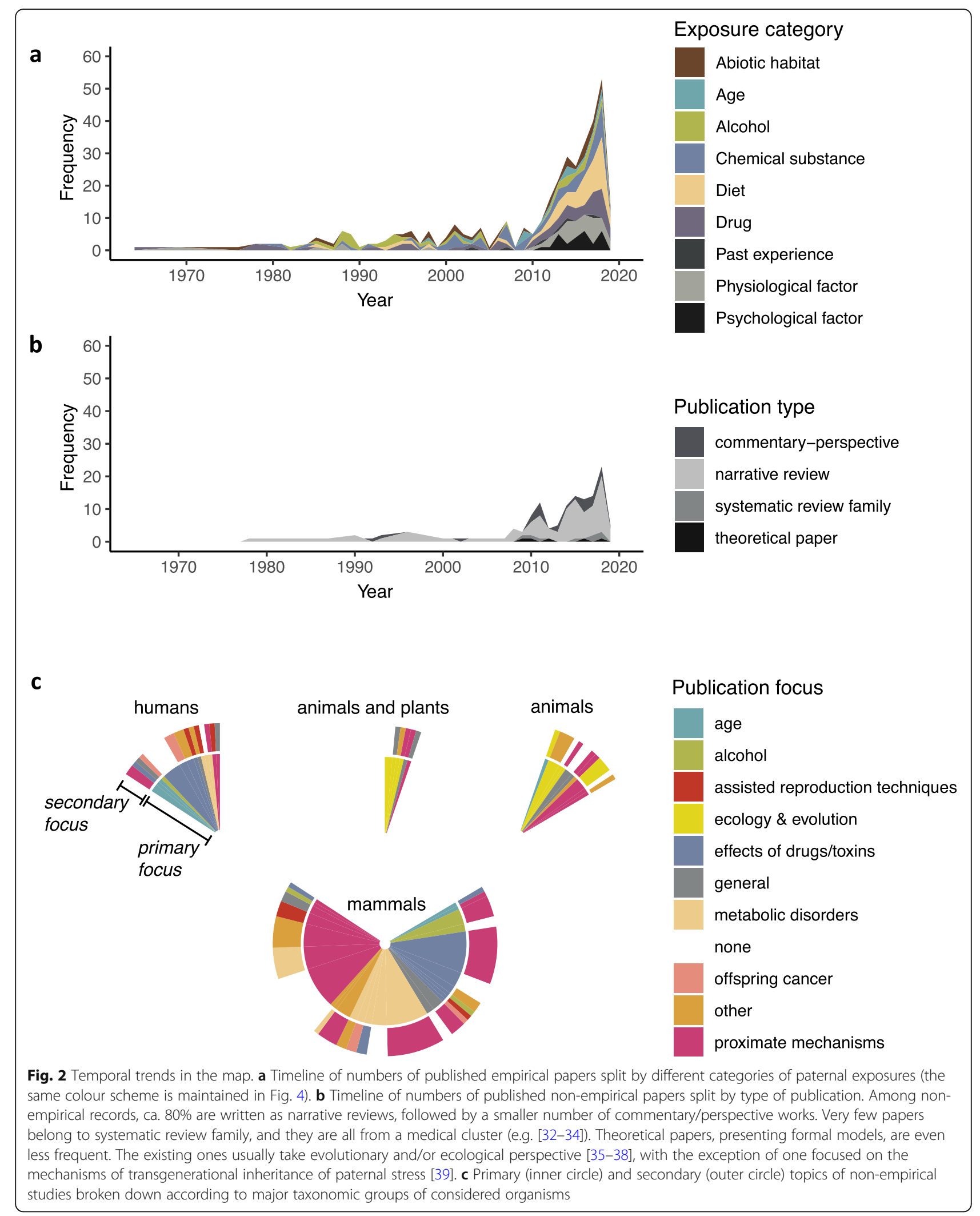


individual publications are poorly connected even within the cluster (Fig. 3b).

The largest cluster belongs to medical scientists. In principle, we would expect that their studies are similar to those of toxicologists, because paternal exposures are also associated with negative effects on human health. However, a much broader scope of medical research makes their studies markedly different. Rodent studies dominate this cluster with relatively few studies on humans and other taxa (Fig. 4a). Medical scientists differ from toxicologists in their higher propensity for experimental, rather than observational, work. The medical cluster is the youngest and has the highest growth rate (Fig. S1).

The third cluster represents the work of eco-evo researchers. They differ from the other two research groups in also considering paternal effects that might be adaptive for the offspring. Eco-evo researchers have studied various taxonomic groups, including plants, arthropods and other invertebrates, fish, birds and, occasionally, rodents, but they have not studied humans, at least in our map (Fig. 4a). Eco-evo researchers frequently work with organisms in the wild or bring wild animals into captivity (Fig. 4a). The eco-evo cluster has an intermediate temporal distribution and rate of growth of publications (Fig. S1).

\section{Influence of and interest in paternal effect research}

Analyses of bibliometric influence (expressed as the number of citations per paper, Fig. 3c) show that, in each cluster, there are highly influential studies, both empirical and non-empirical. To exemplify where the attention of the research field is directed, we consider the three papers, ones with the highest number of citations in each cluster (Fig. 3d). Two of those papers present empirical work: one examines the inheritance of metabolic syndrome [42], while the other study examines how dioxin exposure affects offspring sex ratio [43]. The third highly influential paper is a classic review written from the evolutionary perspective [23]. Surprisingly, no articles in our map cite the paper by $\mathrm{Ng}$ and colleagues [42], which has the highest total number of citations (mostly by articles belonging to the subject area of "biochemistry, genetics and molecular biology", as categorized by Scopus). The paper [42] demonstrates that paternal high-fat diet consumption leads to the intergenerational transmission of impaired glucoseinsulin homeostasis. As such, it would be relevant for researchers studying dietary effects in eco-evo context and those investigating toxicants that alter glucose-insulin homeostasis.

\section{Landscape of experimental approaches}

Experiments on paternal effects pose substantial challenges and complexities. Such experiments should include three parties (fathers, mothers and offspring) in two states (experiment and control), resulting in up to six groups. Notable differences to the most basic experimental design, which involves only one party of subjects divided into experimental and control groups, are twofold. First, researchers apply a treatment to one party of subjects (fathers), but they measure outcomes in different parties (offspring). Second, experiments addressing paternal effects require extra players (mothers), although the researchers usually pay little attention to this extra group. These complications have shaped the current experimental landscape in the paternal effect literature. In this section, we take a tour of this landscape (Fig. 4) through the lens of the three guilds of scientists which we identified in the last section and by following the three 'main characters' of the family story: father, mother and offspring.

\section{Father}

Obviously, fathers (or males) are the heroes of this experimental land. In the description of clusters, we have already uncovered who they are and where they are from. Here, we explore what kinds of challenges (exposures) they experience, and how they experience them.

Types of paternal exposure Eco-evo researchers have a long tradition of studying the paternal effects of diet (Fig. 4a). Also, medical researchers have become increasingly interested in the transgenerational inheritance of the metabolic syndrome due to diet. Naturally, toxicologists have assessed chemical exposure (e.g. pesticides and solvents), mainly in humans, while ecologists measure effects of chemicals (environmental pollutants) on wildlife and non-model species. Somewhat surprisingly, toxicologists have studied the inter/trans-generational effects of medical drugs more than medical scientists. Yet, medical scientists seem to be the only group looking into the effect of paternal alcohol exposure. Both medical researchers and eco-evo researchers have shared their interest in studying (1) physiological exposures via experimental infection and (2) psychological exposures including various social (e.g. isolation or crowding) and physical (e.g. restraint, scent of predator) stressors. Finally, all types of scientists have studied paternal effects in relation to some abiotic aspects, such as water salinity, ambient temperature, electromagnetic field and light exposure.

Interactions, dosage and timing of paternal exposures Most of the time, in a given study, fathers are exposed to only one challenge ( $94 \%$ of all studies). Yet, some researchers in each of the three fields have examined the effects of interaction of different categories of factors 


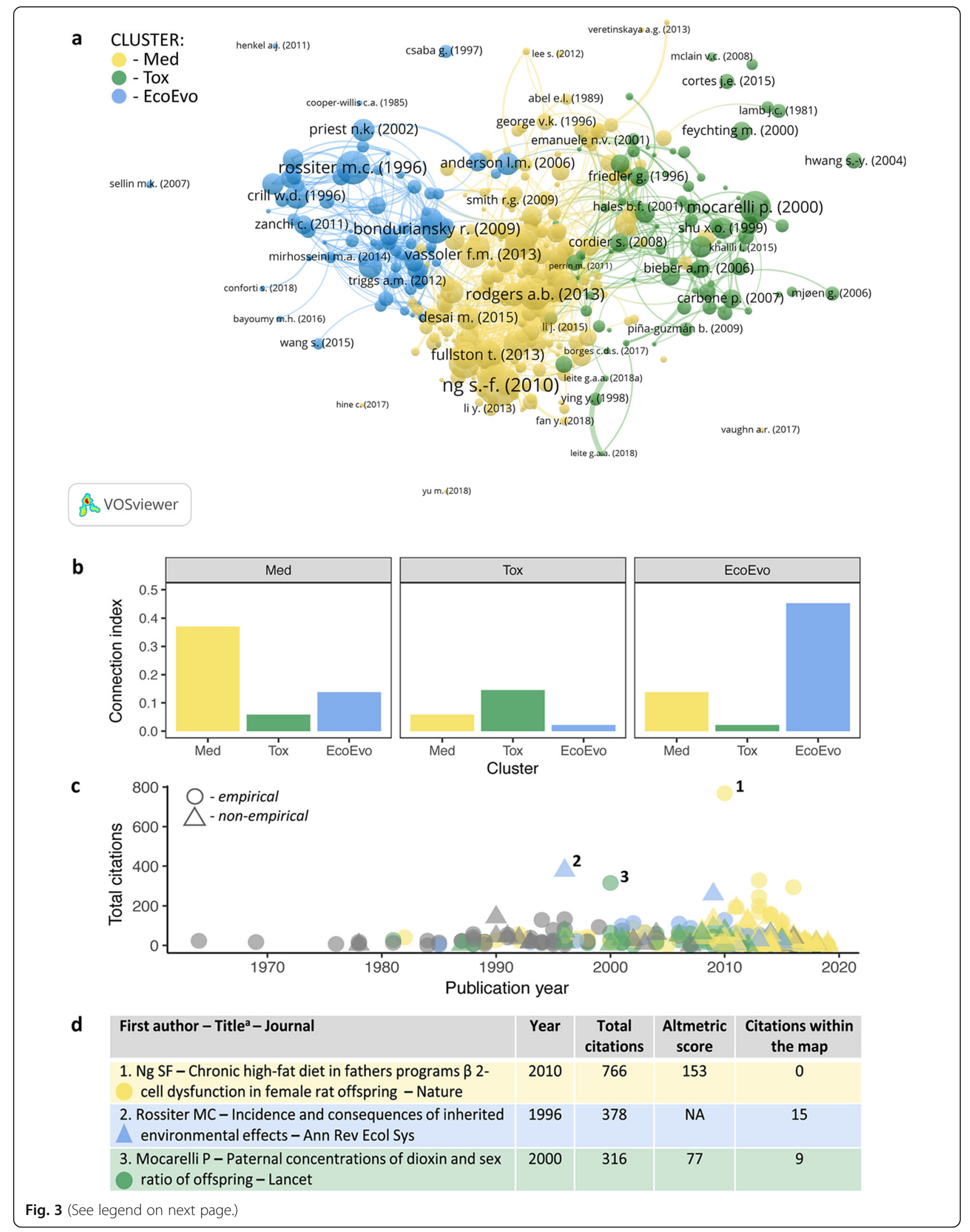


(See figure on previous page.)

Fig. 3 Bibliometric insights into the fragmentation of paternal effect literature. a Clustering of paternal effects literature based on bibliometric coupling analysis performed in VOSviewer [41]. We named the clusters based on their dominant research discipline and assigned them different colours, i.e. medical $(\mathrm{Med})=$ yellow, toxicological $(T o x)=$ green and eco-evolutionary $(E c o E v o)=$ blue. $\mathbf{b}$ Indices of bibliographic connection between papers in the three clusters. c Number of citations of papers included in the map. Grey indicates papers not assigned to any cluster. Numbers mark the top cited paper in each cluster. $\mathbf{d}$ Bibliometric data for the three papers with the highest citation count, one in each cluster; Altmetric Attention Score is a weighted count of all of the online attention

acting on the father (for interacting effects between dietary components, see below). For instance, medical researchers have shown that paternal exercise alleviates the negative effect of obesogenic diet in mice [44, 45]. Eco-evo researchers have uncovered complex interactions between paternal age and immune challenge in insects [46].

It is more common to study dose-related responses to a single factor than interactions (approx. 20\% of all studies). Toxicologists have always conducted dose-dependency studies [47]. Medical researchers also differentiate dosage in their studies of the effects of paternal alcohol exposure $[48,49]$. Similarly, to reveal the effects of paternal age, researchers compare several groups of males of different age [50]. Eco-evo researchers have used gradients of exposures in plant studies [51]. They have also implemented nutritional geometry experiments in animal studies $[52,53]$, which allow them to reveal non-linear and finescale interactive effects of different dietary compounds.

Majority of studies (92\% in toxicological, $79 \%$ in medical, $66 \%$ in eco-evo clusters) manipulate fathers at the adult stage, usually by subjecting them to exposure for one or two cycles of spermatogenesis. Researchers typically use patterns of exposure which mimic what fathers may encounter in real life (e.g. a heat wave [54], different sleep deprivation schedules [55], cocaine intake between weekdays and weekend [56]). Notably, some researchers have manipulated the time passed between exposure and mating. In case of medical drugs, this experimental design allows comparing acute and persistent effects of the exposure [57]. Further, such a design has shown that exposing fathers to chronic stress either at puberty or at adulthood had similar effects on offspring stress axis regulation [58].

\section{Mother}

As in old fairytales, this heroine has been a rather passive participant in the story. However, she has much to offer and can become a true heroine, as in newer stories. We believe that exciting unexplored possibilities exist when both the hero and the heroine face a challenge (exposure) together.

Mate choice and differential allocation The female can mediate the effects of male experiences in two potential, interrelated ways, one direct and one indirect.
Her assessment of male quality can directly affect her prenatal and postnatal maternal investment in offspring [59]. Similarly, yet more indirectly, females could invest in offspring differentially if males induce such response via substances in their ejaculates $[3,4]$. Both of these phenomena-via female perception and male substances-are referred to as maternal 'differential allocation' and have gained much attention, especially in evolutionary literature [60]. Although female differential allocation is interesting in its own right, to understand the magnitude, function and mechanism of paternal effects, we should limit the opportunity for maternally mediated effects.

Indeed, $77 \%$ of researchers across the field have blocked female mate choice by paring up a single male and female (with the exception of human studies). In addition, the researchers predominantly use virgin females (but see [56]). While these two approaches reduce maternal effects due to female perception of male quality, they cannot eliminate them. Eco-evo researchers are most likely to control for differential allocation due to female perception (30\%), usually by capitalizing on species with external fertilization [61] or by the means of artificial fertilization in plants, fish and birds [62]. Researchers in medicine control for maternal effects rarely (12\%), yet using the greatest variety of methods, including in vitro fertilization [63], embryo transfer [64] and offspring cross-fostering [65]. Toxicologists have rarely dealt with this issue (5\%).

Differential allocation induced by male substances is even more challenging to control for, and therefore, only a few have done so to date (e.g. [66]). Nonetheless, researchers could quantify those effects by combining artificial insemination with the use of vasectomized males, which allows assessing the effects of seminal fluid substances. Medical researchers have carried out such studies occasionally [67]. In a similar vein, eco-evo researches have used the so-called telegony approach. Under this approach, a female is mated with two males, both of whom contribute to her offspring phenotypes: the one as a genetic father and the other via semen-mediated effects (only two studies in our collection used this approach $[68,69]$, see also [70]).

Maternal exposure: comparison and synergy Researchers can expose mothers to the same challenges as fathers (Fig. 4b). Such a venture opens up possibilities of answering additional questions, but a careful experimental 

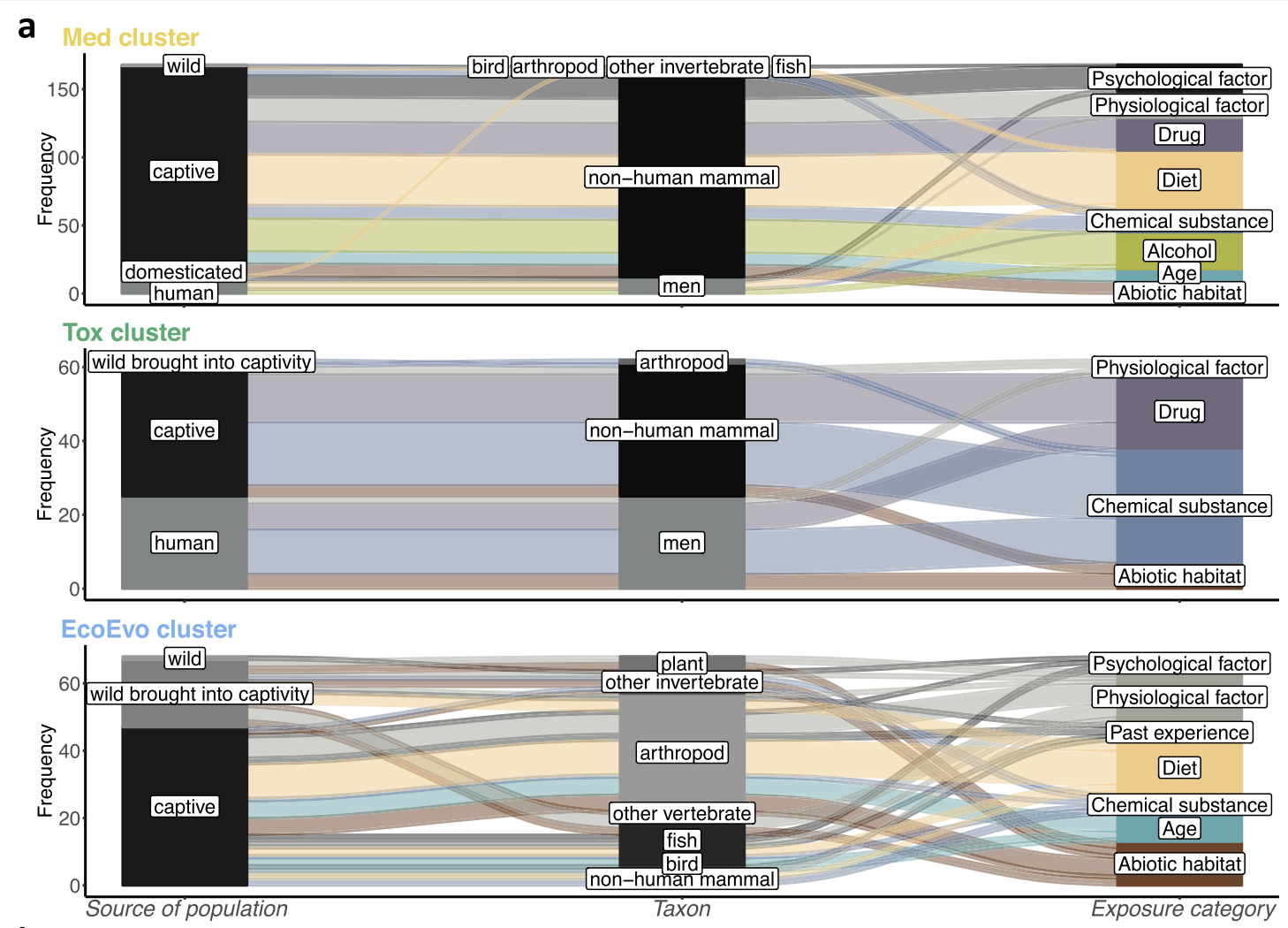

b

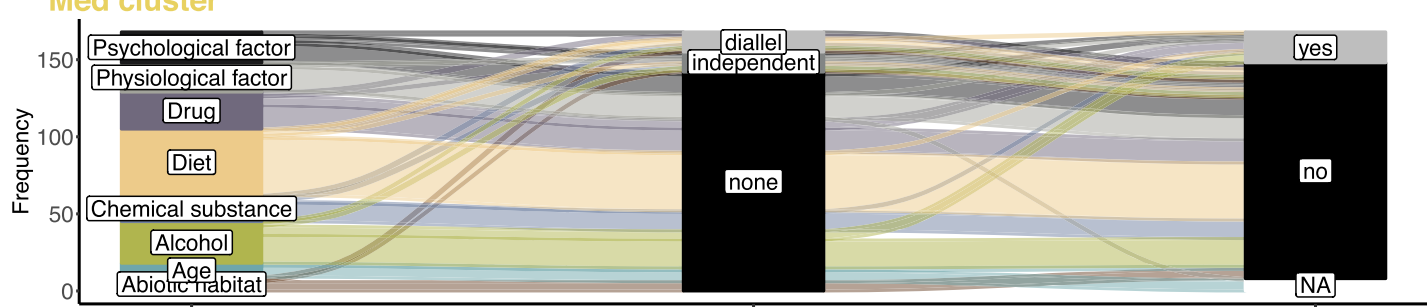

Tox cluster
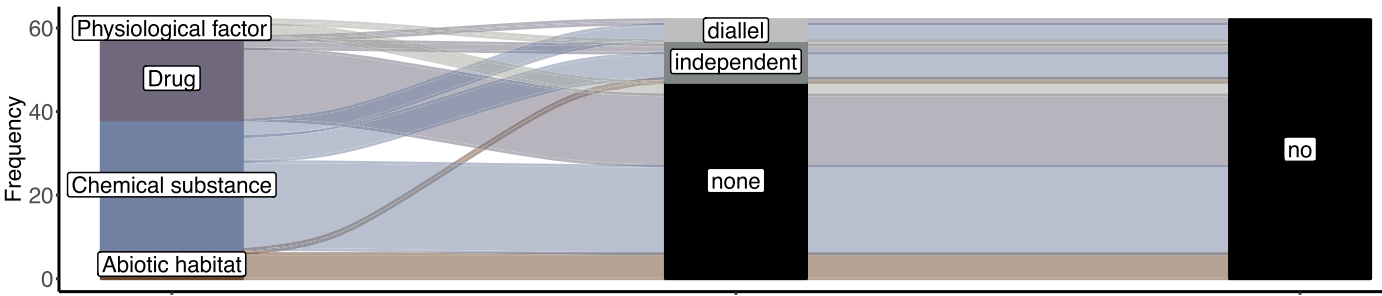

EcoEvo cluster
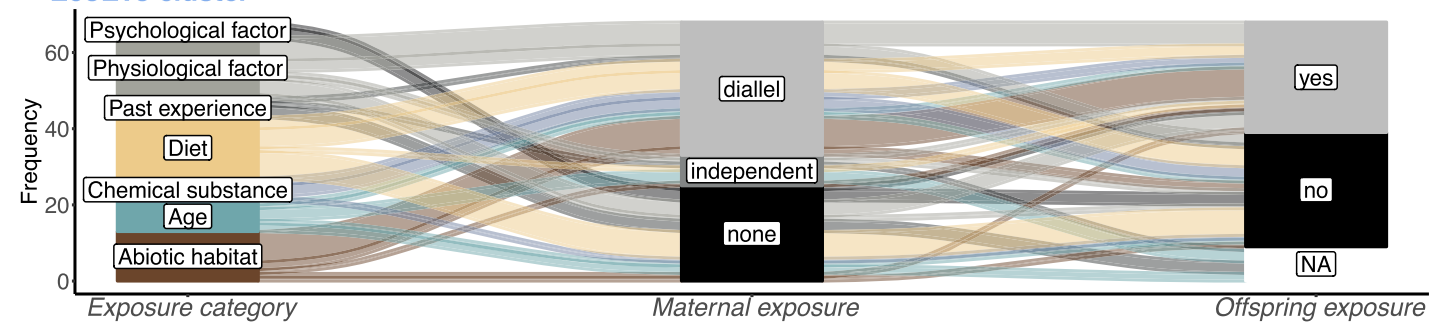

Fig. 4 (See legend on next page.) 
(See figure on previous page.)

Fig. 4 Objects and exposures in paternal effect studies broken down by bibliometric cluster. Plots are based on 302 empirical studies included in the map and assigned to one of the three clusters (Med, Tox and EcoEvo). The size of the panels is proportional to the frequency of studies in a given category. Colour represents the category of experimental exposure (for the legend, see Fig. 2a). a Source of studied species, taxonomic group and category of paternal exposure. $\mathbf{b}$ Category of experimental exposure, information on maternal and offspring exposure to the same factor as the father

design is warranted. Toxicologists commonly use a design comparing two groups of offspring from biparental exposure vs. non-exposure groups (e.g. [71]). Unfortunately, such a simplistic design precludes assessment of paternal (or maternal) effect alone; accordingly, these studies are not included in our map. Assessing the relative strength of paternal compared to maternal effects is possible when we expose fathers and mothers independently and then pair them up with control individuals (see also Fig. 5f). Sometimes, it is inevitable that exposed partners reproduce only with control (e.g. human medical studies [72, 73];), precluding analyses of the effect of combined exposure.

The most informative is a two-by-two factorial design (also known as North Carolina II). This design enables not only comparing the effect of each parent separately, but also estimating the synergistic (interactive) effect of both [74]. Using the factorial design (55\%, Fig. 4b), many of eco-evo researchers have found that the father and mother can have a synergetic effect on offspring (e.g. [75]), but their effects could also cancel each other (e.g. [76]).

\section{Offspring}

Finally, we turn to the children, who are an essential part of the story, but often neglected. Scientists take many different measurements from the children (offspring) at different times, but they often forget that we have both princes and princesses. Moreover, we find some scientists have also challenged the children, enriching the story plot, while others failed to do so.

Measurements: timing, sex-specific and multigenerational effects Toxicologist, more than others, confine their studies to effects on offspring development; only $30 \%$ of their studies track offspring to adulthood. Many medical scientists, in contrast, investigate offspring performance up to adulthood (i.e. $70 \%$, facilitated by the use of relatively fast-maturing lab rodents). Eco-evo researchers also often monitor offspring through development until adulthood (62\%), although their monitoring could stop at the juvenile (or larval) stage. Therefore, data on offspring phenotype in the three clusters complement each other, highlighting possibilities of knowledge transfer across the disciplines in this respect.

Researchers who cease the study at early stages of offspring development usually lack information on offspring sex. This, however, only partly explains why over half of the studies of paternal effects do not take into account offspring sex. Although toxicologists have been interested in whether paternal exposure affects sex ratio [77], surprisingly, they are also the least likely to account for offspring sex (34\%) in assessing offspring traits. In contrast, medical scientists are the keenest to report effects for the two sexes separately, but also to study only one sex (65\% for those two approaches combined). Given the interest in parent-of-origin epigenetic inheritance (Table 1), researchers should routinely examine sex specificity of paternal effects in the offspring [78, 79]. Unfortunately, this is not the case. Instead, the large body of existing literature (63\%) has not taken opportunities to detect such sex-specific patterns.

Our map has shown that only ca. $10 \%$ of studies examined the transfer of paternal effects to the grandoffspring generation or beyond. Yet, a multigenerational study can provide insights into the nature and persistence of paternal effects. The medical cluster has included such multigenerational studies: the consequences of F0 generation exposure to high-fat diet [80] and heroin addiction [81], in both of which paternal effects were followed up to F3 generation descendants.

Offspring exposure: matching, mismatching and beyond As mentioned earlier, medical scientists and toxicologists have focused on the negative effects of paternal exposures. Thus, it may not be surprising that toxicologists never expose offspring to the same damaging factors (chemicals and drugs, Fig. 4b), although medical scientists have sometimes done so (12\%). In contrast, nearly half $(47 \%)$ of the eco-evo researchers expose offspring to the same factor as fathers. They compare offspring under matched and mismatched conditions to those experienced by their fathers to see if fathers prepare offspring for the same environment via so-called anticipatory paternal effects (sensu [82, 83]). However, to properly investigate anticipatory paternal effects, the experimental design should be based on environmental predictability over the space and time [84]. A proper study should include evidence of the likelihood that the offspring generation will face the same environment as their fathers [84]. In practice, we are aware of no such studies.

\section{Gaps and opportunities: three examples}

We have highlighted what researchers have done so far. Yet, systematic mapping can also elucidate knowledge gaps in the research field [29]. Here, among many potential gaps, 
Rutkowska et al. BMC Biology

(2020) 18:183

Page 10 of 24

a

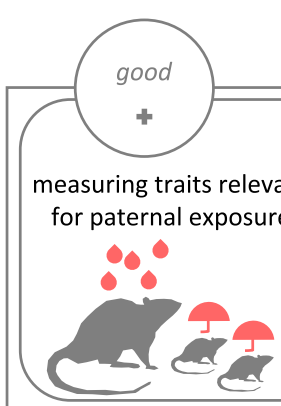

Empirical research approaches: design / clarity

adaptiveness of paternal effects

exposing offspring to the

measuring same factor as fathers offspring fitness

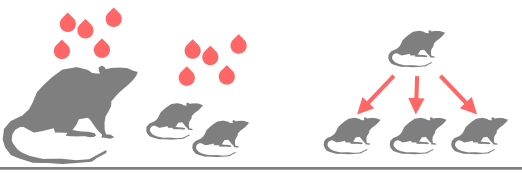

relative strength of paternal versus maternal effects and their interaction

within-group mating only paternal exposure

C maternal-mediated effects via the female perception

assessment of female preferences

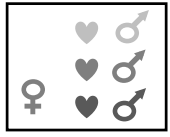

assessment of offspring cross-fostering maternal behavior or embryo transfer

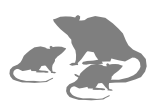

North Carolina II design

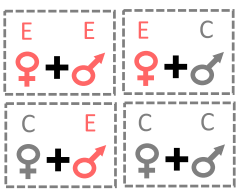
in vitro fertilization
or artificial insemination

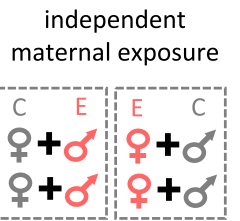

fertilization

d maternal differential allocation via opportunity for mate choice best

providing cues on the expected offspring environment
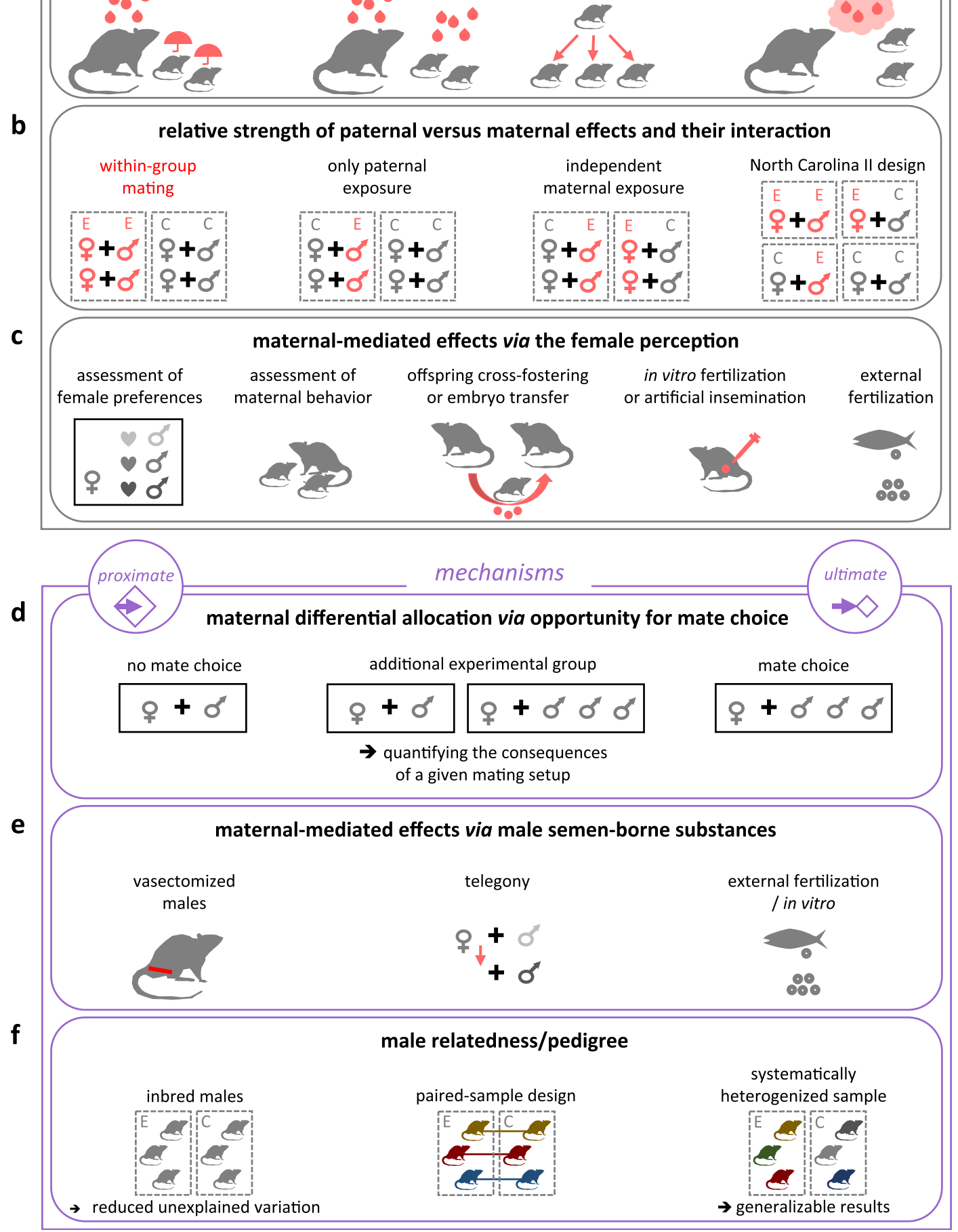

Fig. 5 (See legend on next page.) 
(See figure on previous page.)

Fig. 5 Six useful considerations for paternal effect research. a To assess the adaptiveness of paternal effects, measure offspring traits relevant for paternal exposure and, optimally, expose some offspring to the same factor as the father. If possible, study offspring fitness traits. For the best outcomes, include cues that allow prediction of the offspring environment by the fathers. $\mathbf{b}$ To measure the relative strength of paternal vs. maternal effects, expose female to the same factor as male. Do not mate the parents only within the experimental group (red indicates the design to be avoided). Pair-up exposed parents with control partners to compare maternal and paternal effects. Use North Carolina II design to assess the synergistic effects of both parents. c To estimate maternal-mediated effects due to females' perception, assess female preference for the male and/or maternal behaviour in relation to paternal treatment. Use embryo transfer and offspring cross-fostering. To eliminate effects due to female perception, use in vitro fertilization and artificial insemination. Study species with external fertilization. $\mathbf{d}$ Allow mate choice, if interested in ultimate aspects of paternal effects. Reduce mate choice, if searching for proximate mechanisms. Add experimental groups to understand the consequences of a particular mating set-up. e To reduce maternal-mediated effects due to male semen-borne substances, use vasectomized males, helping identify the proximate mechanism of paternal effects. One could also use telegony approach. To separate female-mediated effects (via male substances and female perception), use species with external fertilization. $\mathbf{f}$ Use highly related males to reduce unexplained variation and facilitate identification of proximate mechanisms of paternal effects. To obtain robust results, use heterogeneous, randomized sample of males. Using males in a paired-sample design could often be a convenient and powerful option

we choose to discuss three examples and show how we can turn these gaps into future research opportunities.

\section{Oversight over paternal effects in livestock?}

Our map, somewhat surprisingly, revealed that paternal effects are neglected in the field of animal breeding (Fig. 4a). In the livestock industry, the choice of sire that produces hundreds of offspring is of paramount importance, and thus, the sire should be of prime quality. Selection schemes of sires usually employ quantitative genetic tools. Thus, much of heritability (due to genetics) is accounted for. However, simultaneous accounting for the epigenome should improve the accuracy of prediction of breeding values. Indeed, among researchers studying farm animals/livestock breeding, there is already an interest in non-genetic paternal inheritance due to sexspecific gene expression patterns [85]; see also Table 1. In terms of environmentally induced paternal effects, it remains unknown what treatment to impose on fathers and which traits to measure in their offspring $[17,86,87]$. Our map could inspire potential research pathways in this field. For example, one of the promising directions would be to explore trans-generational effects related to immunity. So far, research shows that paternal immunization enhances embryonic growth in mice [88], and treating fathers with Astragalus polysaccharides increase offspring immunity in the chicken [62]. A recent paper has presented a mathematical model incorporating non-genetic inheritance in livestock breeding [89]. This model could help in designing breeding schemes suitable for investigating non-genetic paternal effects. Last but not least, we could use data from livestock to address the significance of relatedness among males, which is our next topic.

\section{Understanding relatedness among fathers for generalisability}

Relatedness of studied fathers is approached in a range of ways. They span from use of lab animals without any reference to their inter-relatedness or pedigree (e.g. [90]), use of hybrids of two mouse strains [58], to use of outbred animals [91]. So, what is best? To detect environmentally induced paternal effects, males exposed to the experimental treatments should ideally have counterparts which differ from them as little as possible (Fig. 5f). This design is possible in highly inbred strains. However, findings could be too specific, for example, due to strain-specific reaction norms [92], and thus not transferrable even to other strains of the same species (see also [93]). One solution is to use systematic heterogenization (i.e. controlled and systematic variation of animals and their environment within a single experiment), which improves the representativeness of study individuals [94]. If this is not possible, we recommend assigning full brothers to control and experimental treatment, as in a paired design [95], which results in higher statistical power than in an unpaired design counterpart.

\section{In search of paternal bet-hedging}

In the face of a stressful and unpredictable environment, mothers should increase variance in offspring traits by employing a so-called bet-hedging strategy [96]. Environmentally stressed fathers should use a similar strategy, as long as the fitness benefits to the male outweigh the costs of investing in such a strategy. Yet, although maternal bethedging has been a popular research topic, and the outcomes of the existing studies are mixed [96], we are not aware of any studies examining bet-hedging (via nongenetic effects) by fathers. This gap could be addressed in a number of ways. In terms of empirical studies, the most intuitive approach would be to manipulate the variability of paternal environment and analyse the difference in variance in offspring between treatment groups (i.e. test for heteroscedasticity [97]). Such a study should differentiate between an adaptive male strategy of producing offspring with increased phenotypic variance and a non-adaptive effect of stressful environment on male reproductive physiology. A meta-analytical approach to study paternal bet-hedging is also possible [98], providing that paternal exposures can be 
unambiguously classified as those that should promote increased or reduced variation in offspring traits. Finally, a recent theoretical model of genomic imprinting [99] predicts reduced variation in offspring phenotype due to paternally (compared to maternally) expressed genes, if males have higher reproductive variance. So far, there are no theoretical models predicting how environmentally induced non-genetic paternal effects affect variation in offspring traits. Thus, such a model is needed.

\section{Improving paternal effect research for posterity}

We have given you a guided tour of our map of the parental effect research through the lens of the three guilds of researchers, three family members and three examples of research gaps. Based on our journey, we offer six considerations for designing future experiments on paternal effects:

a) Assessing whether paternal effects benefit offspring health and fitness

b) Quantifying paternal, maternal and their interactive effects

c) Lessening or eliminating maternally mediated effects via female perception

d) Allowing opportunities for mate choice to study maternal differential allocation

e) Isolating or eliminating maternally mediated effects via male semen-borne substances

f) Considering male relatedness to reduce confounds or enhance generalisability

The first three considerations are useful for singling out paternal effects and clarifying their function, whereas the latter three are concerned with designs suitable for understanding proximate or ultimate mechanisms (Fig. 5). All the considerations provide options depending on researchers' interest, their study organisms and other logistics. They also provide opportunities for cross-fertilizations of approaches and ideas from the three clusters of scientists. For example, medical researchers often employ sophisticated techniques to elucidate the proximate mechanisms mediating paternal effects [63, 64], and some of these techniques could be utilized by other researchers. Conversely, eco-evo researchers test predictions derived from theory $[22,23]$ and focus their experiments on ecologically relevant effects. Some of the insights gained from evolutionary and ecological theory could inform the design of medical and toxicological research [4]. Toxicologists typically investigate the effects of a range of treatment levels [47], and such an approach can facilitate the detection of subtle or non-linear effects of the paternal environment on offspring. Such inter-disciplinary links between the three clusters could enhance paternal effect research overall.

\section{Conclusions}

Research into paternal effects is multidisciplinary. However, currently, three relatively insular clusters exist in this research field. We call for more cross-disciplinary collaborations among the three guilds. Further, we note that the importance of paternal effects does not stop at the individual level and that paternally induced changes could propagate into the population and meta-population scales [100]. Altogether, we have much to hope for in the future of the paternal effect research. It will bridge disparate fields of research and will continue to provide useful insights into topics ranging from public health, environmental pollution and climate change to animal science. We can also expect much interest from members of the public by showing that there might be much more than genes to the saying 'like father, like son'.

\section{Methods}

\section{Systematic map}

The map is based on the published papers on environmentally induced non-genetic paternal germline and semen effects (i.e. when the male had been exposed to some environmental factor before fertilization and the effects were studied in the offspring anytime from the fertilization onwards; Fig. 1a); importantly, it does not include the effects of paternal care, which role is well documented [101-103]. PECO (Population, Exposure, Comparators and Outcomes) statement is available in Additional File: Table S1.

Relevant records were identified via searches carried out in Scopus and Web of Science databases on 11 April 2019. Sets of keywords are summarized in Fig. 1b, see also Additional File for the exact search string.

The procedure applied after the literature search is presented in a PRISMA diagram [28] (Fig. 3c). In short, we uploaded unique records to Rayyan (https://rayyan. qcri.org/) to perform the initial screening based on the title, abstract and keywords. The screening was done independently by two researchers. We excluded records that did not fulfil all the criteria outlined in the PECO statement. We classified records that fulfilled the inclusion criteria as empirical or non-empirical. We used the Zotero reference manager (https://www.zotero.org/) to retrieve full texts of the designated records. One person coded full texts, with 42 cross-checked by the second person. We uploaded separate datasets of empirical (references [42-58, 61-65, 67-69, 72-77, 80, 81, 83, 88, 90, 91, 104-404]) and non-empirical (references [3-6, 11, $19,20,23-25,32-39,87,103,405-518]$ ) layers into $\mathrm{R}$ v.3.6.0 [519] and visualized their content using ggplot2 package [520]. We analysed the combined datasets $\mathrm{w}$ using the bibliometrix package [41] and VOSviewer (https://www.vosviewer.com/) [521]. Full details of the methods are provided in the Additional File. 


\section{Bibliometric analyses}

We downloaded relevant bibliometric records from Scopus database on 16 July 2019. We ran bibliometric coupling analysis in VOSviewer [521] to find clusters in paternal effect literature (Fig. 3a). The unit of analysis was 'document' (i.e. each paper). We used a factorial counting method, which equalizes the weight given to each paper, regardless of whether it has been cited, and fractionalization method to visualize the outcome. Clustering resolution was set to 0.8 and minimal cluster size to 60 . The resulting number of three clusters was a stable outcome when minimal cluster size parameter was varied between 51 and 79 . We named the clusters based on their dominant research discipline, i.e. medical (Med), toxicological (Tox) and eco-evolutionary (EcoEvo).

We calculated the index of bibliographic connection between papers in the three clusters (Fig. 3b) following [522]. The index parameter reflects how many connections are there given the number of all possible connections that could exist between two different clusters and with the cluster itself. The mean connectivity index for our clusters is 0.16 due to low connectivity between clusters and also within clusters themselves. To put this index value into perspective, life-history theory literature, analysed using the same approach, was characterized by a mean index of 0.56 for studies published before 2010 and 0.35 for those published after 2010 [522]. Low connectivity indices may be linked to a rapid increase of volume of available research (although it is not a default relationship), but it may also indicate that literature relevant to a given topic goes unnoticed.

\section{Supplementary Information}

Supplementary information accompanies this paper at https://doi.org/10. 1186/s12915-020-00892-3.

Additional file 1. 1. Additional results (Figure S1). Temporal distribution of records belonging to the three clusters. 2. Paternal effects PECO statement regarding empirical papers (Table S1). 3. Search string. 4. Decision trees for initial screening based on abstracts, titles and keywords (Figure S2, Figure S3). 5a. Additional information on selection criteria. 5b. Limitations of the map. 6a. Questionnaire 1, used in full-text coding for the purpose of the map of empirical records. 6b. Questionnaire 2, used in full-text coding for the purpose of the map of non-empirical records. 7 . Amendments to the initial protocol. 8a. List of papers excluded based on full text with the reasons - non-empirical layer. 8b. List of papers excluded based on full text with the reasons - empirical layer.

\section{Acknowledgements}

We thank the editor and three anonymous reviewers for their useful comments.

\section{Authors' contributions}

$J R$ conceived and led the designing of the study. JR and ML performed the initial trials leading to the choice of the search string and pilot rounds of abstract exclusion and full-text coding. JR carried out the full-text coding and analyses with input from ML and SN. JR and SN wrote the paper with input from $\mathrm{ML}$ and RB. All authors discussed the project and contributed to the final version. The authors read and approved the final manuscript.

\section{Funding}

JR was supported by the Polish National Agency for Academic Exchange. SN and $M L$ are supported by the ARC grant (DP180100818). The open-access publication of this article was funded by the Priority Research Area BioS under the program "Excellence Initiative - Research University" at the Jagiellonian University in Krakow and by the Polish National Agency for Academic Exchange.

Availability of data and materials

Data and code are available from https://osf.io/ehy3n/.

Ethics approval and consent to participate

Not applicable.

\section{Consent for publication}

Not applicable.

\section{Competing interests}

The authors declare that they have no competing interests.

Received: 19 May 2020 Accepted: 8 October 2020

Published online: 27 November 2020

\section{References}

1. Mousseau TA, Fox CW. The adaptive significance of maternal effects. Trends Ecol Evol. 1998;13(10):403-7.

2. Wolf JB, Brodie lii ED, Cheverud JM, Moore AJ, Wade MJ. Evolutionary consequences of indirect genetic effects. Trends Ecol Evol. 1998;13(2):64-9.

3. Crean AJ, Bonduriansky R. What is a paternal effect? Trends Ecol Evol. 2014; 29(10):554-9.

4. Curley JP, Mashoodh R, Champagne FA. Epigenetics and the origins of paternal effects. Horm Behav. 2011;59(3):306-14.

5. Hur SSJ, Cropley JE, Suter CM. Paternal epigenetic programming: evolving metabolic disease risk. J Mol Endocrinol. 2017;58(3):R159-68.

6. Champroux A, Cocquet J, Henry-Berger J, Drevet JR, Kocer A. A decade of exploring the mammalian sperm epigenome: paternal epigenetic and transgenerational inheritance. Front Cell Dev Biol. 2018;6:50.

7. Crean AJ, Adler MI, Bonduriansky R. Seminal fluid and mate choice: new predictions. Trends Ecol Evol. 2016;31(4):253-5.

8. Núñez J, Castro D, Fernández C, Dugué R, Chu-Koo F, Duponchelle F, García C, Renno J-F. Hatching rate and larval growth variations in

Pseudoplatystoma punctifer: maternal and paternal effects. Aquac Res. 2011; 42(6):764-75

9. Hamann H, Steinheuer R, Distl O. Estimation of genetic parameters for litter size as a sow and boar trait in German herdbook Landrace and Pietrain swine. Livest Prod Sci. 2004;85(2-3):201-7.

10. Friberg U, Stewart Andrew D, Rice William R. X- and Y-chromosome linked paternal effects on a life-history trait. Biol Lett. 2012;8(1):71-3.

11. Rando OJ. Daddy issues: paternal effects on phenotype. Cell. 2012;151(4): 702-8.

12. Malo AF, Gilbert TC, Riordan P. Drivers of sex ratio bias in the eastern bongo: lower inbreeding increases the probability of being born male. Proc R Soc B Biol Sci. 2019;286(1902):20190345

13. Damiani C, Ricci I, Crotti E, Rossi P, Rizzi A, Scuppa P, Esposito F, Bandi C, Daffonchio D, Favia G. Paternal transmission of symbiotic bacteria in malaria vectors. Curr Biol. 2008;18(23):R1087-8.

14. Liu C, Wang J-L, Zheng Y, Xiong E-J, Li J-J, Yuan L-L, Yu X-Q, Wang Y-F. Wolbachia-induced paternal defect in Drosophila is likely by interaction with the juvenile hormone pathway. Insect Biochem Mol Biol. 2014;49:49-58.

15. Luo S, Valencia CA, Zhang J, Lee N-C, Slone J, Gui B, Wang X, Li Z, Dell S, Brown J, et al. Biparental inheritance of mitochondrial DNA in humans. Proc Natl Acad Sci. 2018;115(51):13039-44.

16. Mendoza C, Greco E, Tesarik J. Late, but not early, paternal effect on human embryo development is related to sperm DNA fragmentation. Hum Reprod. 2004;19(3):611-5.

17. Gonzalez-Recio O, Toro M, Bach A. Past, present and future of epigenetics applied to livestock breeding. Front Genet. 2015;6:305.

18. Skinner MK. Environmental epigenetics and a unified theory of the molecular aspects of evolution: a neo-Lamarckian concept that facilitates neo-Darwinian evolution. Genome Biol Evol. 2015;7(5):1296-302. 
19. Mashoodh R, Champagne FA. Paternal epigenetic inheritance; 2014. p. 221-35.

20. Janecka M, Mill J, Basson MA, Goriely A, Spiers H, Reichenberg A, Schalkwyk $L$, Fern e C. Advanced paternal age effects in neurodevelopmental disorders-review of potential underlying mechanisms. Transl Psychiatry. 2017;7:e1019.

21. Horvath S, Gurven M, Levine ME, Trumble BC, Kaplan H, Allayee H, Ritz BR, Chen B, Lu AT, Rickabaugh TM, et al. An epigenetic clock analysis of race/ ethnicity, sex, and coronary heart disease. Genome Biol. 2016;17(1):171.

22. Bonduriansky R, Day T. Extended heredity: a new understanding of inheritance and evolution. Extended Hered. 2018;Princeton University Press, 288 pp.

23. Rossiter MC. Incidence and consequences of inherited environmental effects. Annu Rev Ecol Syst. 1996;27:451-76.

24. Soubry A. Epigenetics as a driver of developmental origins of health and disease: did we forget the fathers? BioEssays. 2018;40(1).

25. Downey AM, Robaire B, Hales BF. Paternally mediated developmental toxicity. Editor(s): Charlene A. McQueen, Comprehensive Toxicology (Third Edition), Elsevier, 2018;100-117.

26. Ioannidis JPA, Fanelli D, Dunne DD, Goodman SN. Meta-research: evaluation and improvement of research methods and practices. PLoS Biol. 2015; 13(10):e1002264

27. Nakagawa S, Noble DWA, Senior AM, Lagisz M. Meta-evaluation of metaanalysis: ten appraisal questions for biologists. BMC Biol. 2017;15(1):18.

28. Moher D, Liberati A, Tetzlaff J, Altman DG. The PG: Preferred Reporting Items for Systematic Reviews and Meta-Analyses: the PRISMA statement. PLoS Med. 2009;6(7):e1000097.

29. Nakagawa S, Samarasinghe G, Haddaway NR, Westgate MJ, O'Dea RE, Noble DWA, Lagisz M. Research weaving: visualizing the future of research synthesis. Trends Ecol Evol. 2019;34(3):224-38.

30. Haddaway NR, Bernes C, Jonsson B-G, Hedlund K. The benefits of systematic mapping to evidence-based environmental management. Ambio. 2016; 45(5):613-20.

31. James $\mathrm{KL}$, Randall NP, Haddaway NR. A methodology for systematic mapping in environmental sciences. Environ Evid. 2016;5(1):7.

32. Campbell JM, Lane M, Owens JA, Bakos HW. Paternal obesity negatively affects male fertility and assisted reproduction outcomes: a systematic review and meta-analysis. Reprod BioMed Online. 2015:31(5):593-604.

33. Oldereid NB, Wennerholm UB, Pinborg A, Loft A, Laivuori H, Petzold M, Romundstad LB, Söderström-Anttila V, Bergh C. The effect of paternal factors on perinatal and paediatric outcomes: a systematic review and meta-analysis. Hum Reprod Update. 2018;24(3):320-89.

34. Walker VR, Boyles AL, Pelch KE, Holmgren SD, Shapiro AJ, Blystone CR, Devito MJ, Newbold RR, Blain R, Hartman P, et al. Human and animal evidence of potential transgenerational inheritance of health effects: an evidence map and state-of-the-science evaluation. Environ Int. 2018;115:48-69.

35. Bonduriansky R, Day T. Nongenetic inheritance and its evolutionary implications. Annu Rev Ecol Evol Syst. 2009;40:103-25.

36. Bonduriansky R, Day T. Nongenetic inheritance and the evolution of costly female preference. J Evol Biol. 2013;26(1):76-87.

37. Bonilla MM, Zeh JA, Zeh DW. An epigenetic resolution of the lek paradox. BioEssays. 2016;38(4):355-66.

38. Revardel E, Franc A, Petit RJ. Sex-biased dispersal promotes adaptive parental effects. BMC Evol Biol. 2010;10:217.

39. Lei J, Nie Q, Chen DB. A single-cell epigenetic model for paternal psychological stress-induced transgenerational reprogramming in offspring. Biol Reprod. 2018;98(6):846-55.

40. Moher D, Stewart L, Shekelle P. All in the family: systematic reviews, rapid reviews, scoping reviews, realist reviews, and more. Syst Rev. 2015;4:183.

41. van Eck NJ, Waltman L. Software survey: VOSviewer, a computer program for bibliometric mapping. Scientometrics. 2010;84(2):523-38.

42. Ng S-F, Lin RCY, Laybutt DR, Barres R, Owens JA, Morris MJ. Chronic high-fat diet in fathers programs [bgr]-cell dysfunction in female rat offspring. Nature. 2010;467(7318):963-6.

43. Mocarelli $P$, Gerthoux PM, Ferrari E, Patterson DG Jr, Kieszak SM, Brambilla P, Vincoli N, Signorini S, Tramacere P, Carreri V, et al. Paternal concentrations of dioxin and sex ratio of offspring. Lancet. 2000;355(9218):1858-63.

44. McPherson NO, Fullston T, Bakos HW, Setchell BP, Lane M. Obese father's metabolic state, adiposity, and reproductive capacity indicate son's reproductive health. Fertil Steril. 2014;101(3):865-73. e861.
45. Stanford KI, Rasmussen M, Baer LA, Lehnig AC, Rowl LA, White JD, So K, De Sousa-Coelho AL, Hirshman MF, et al. Paternal exercise improves glucose metabolism in adult offspring. Diabetes. 2018;67(12):2530-40.

46. Nystrand M, Dowling DK. Transgenerational interactions involving parental age and immune status affect female reproductive success in Drosophila melanogaster. Proc R Soc B Biol Sci. 2014;281(1794): 20141242.

47. Valcarce DG, Vuelta E, Robles V, Herraez MP. Paternal exposure to environmental 17-alpha-ethinylestradiol concentrations modifies testicular transcription, affecting the sperm transcript content and the offspring performance in zebrafish. Aquat Toxicol. 2017;193:18-29.

48. Abel EL, Lee JA. Paternal alcohol exposure affects offspring behavior but not body or organ weights in mice. Alcohol Clin Exp Res. 1988; 12(3):349-55.

49. Lee HJ, Ryu JS, Choi NY, Park YS, Kim Yl, Han DW, Ko K, Shin CY, Hwang HS, Kang KS, et al. Transgenerational effects of paternal alcohol exposure in mouse offspring. Anim Cells Syst. 2013;17(6):429-34.

50. García-Palomares S, Pertusa JF, Miñarro J, García-Pérez MA, Hermenegildo C Rausell F, Cano A, Tarín JJ. Long-term effects of delayed fatherhood in mice on postnatal development and behavioral traits of offspring. Biol Reprod. 2009;80(2):337-42

51. Galloway LF. Parental environmental effects on life history in the herbaceous plant Campanula americana. Ecology. 2001;82(10):2781-9.

52. Bonduriansky R, Runagall-McNaull A, Crean AJ. The nutritional geometry of parental effects: maternal and paternal macronutrient consumption and offspring phenotype in a neriid fly. Funct Ecol. 2016;30(10):1675-86.

53. Polak M, Simmons LW, Benoit JB, Ruohonen K, Simpson SJ, Solon-Biet SM. Nutritional geometry of paternal effects on embryo mortality. Proc R Soc B Biol Sci. 2017;284:20171492.

54. Zhu B, Walker SK, Oakey H, Setchell BP, Maddocks S. Effect of paternal heat stress on the development in vitro of preimplantation embryos in the mouse. Andrologia. 2004;36(6):384-94.

55. Gao HH, Li JT, Zhao N, Zhang L, Fu Y, Zhang YJ, Chen RX, Zhang JM. Biobehavioral effects produced by paternal sleep disturbances. Sleep Biol Rhythms. 2015;13(3):235-41.

56. George VK, Li H, Teloken C, Grignon DJ, Lawrence WD, Dhabuwala CB. Effects of long-term cocaine exposure on spermatogenesis and fertility in peripubertal male rats. J Urol. 1996;155(1):327-31.

57. Favareto AP, de Toledo FC, Kempinas Wde G. Paternal treatment with cisplatin impairs reproduction of adult male offspring in rats. Reprod Toxicol. 2011;32(4):425-33.

58. Rodgers AB, Morgan CP, Bronson SL, Revello S, Bale TL. Paternal stress exposure alters sperm microRNA content and reprograms offspring HPA stress axis regulation. J Neurosci. 2013;33(21):9003-12.

59. Sheldon BC. Differential allocation: tests, mechanisms and implications. Trends Ecol Evol. 2000;15(10):397-402.

60. Champagne FA. Interplay between paternal germline and maternal effects in shaping development: the overlooked importance of behavioural ecology. Funct Ecol. 2020;34(2):401-13.

61. Jensen N, Allen RM, Marshall DJ. Adaptive maternal and paternal effects: gamete plasticity in response to parental stress. Funct Ecol. 2014;28(3):724-33

62. Li Y, Lei X, Guo W, Wu S, Duan Y, Yang X, Yang X. Transgenerational endotoxin tolerance-like effect caused by paternal dietary Astragalus polysaccharides in broilers' jejunum. Int J Biol Macromol. 2018;111:769-79.

63. Chen $\mathrm{Q}$, Yan MH, Cao ZH, Li X, Zhang YF, Shi JC, Feng GH, Peng HY, Zhang $X D$, Zhang $Y$, et al. Sperm tsRNAs contribute to intergenerational inheritance of an acquired metabolic disorder. Science. 2016;351(6271):397-400.

64. Mashoodh R, Habrylo IB, Gudsnuk KM, Pelle G, Champagne FA. Maternal modulation of paternal effects on offspring development. Proc R Soc B Biol Sci. 2018:285(1874):20180118.

65. Dai JB, Wang ZX, Xu WJ, Zhang MX, Zhu ZJ, Zhao XL, Zhang D, Nie DS, Wang LY, Qiao ZD. Paternal nicotine exposure defines different behavior in subsequent generation via hyper-methylation of mmu-miR-15b. Sci Rep. 2017:7(1):7286

66. Simmons LW. Allocation of maternal- and ejaculate-derived proteins to reproduction in female crickets, Teleogryllus oceanicus. J Evol Biol. 2011; 24(1):132-8

67. Watkins AJ, Dias I, Tsuro H, Allen D, Emes RD, Moreton J, Wilson R, Ingram RJM, Sinclair KD. Paternal diet programs offspring health through spermand seminal plasma-specific pathways in mice. Proc Natl Acad Sci U S A. 2018;115(40):10064-9. 
68. Crean AJ, Kopps AM, Bonduriansky R. Revisiting telegony: offspring inherit an acquired characteristic of their mother's previous mate. Ecol Lett. 2014; 17(12):1545-52.

69. Eggert H, Kurtz J, Diddens-de Buhr MF. Different effects of paternal transgenerational immune priming on survival and immunity in step and genetic offspring. Proc R Soc B Biol Sci. 2014;281:0142089.

70. Simmons LW, Lovegrove M. Nongenetic paternal effects via seminal fluid. Evol Lett. 2019;3(4):403-11.

71. Ganiger S, Malleshappa HN, Krishnappa H, Rajashekhar G, Ramakrishna Rao V, Sullivan F. A two generation reproductive toxicity study with curcumin, turmeric yellow, in Wistar rats. Food Chem Toxicol. 2007;45(1):64-9.

72. Zuccolo L, DeRoo LA, Wills AK, Smith GD, Suren P, Roth C, Stoltenberg C, Magnus P. Pre-conception and prenatal alcohol exposure from mothers and fathers drinking and head circumference: results from the Norwegian Mother-Child Study (MoBa). Sci Rep. 2016;6:39535.

73. Messerlian C, Bellinger D, Mínguez-Alarcón L, Romano ME, Ford JB, Williams PL, Calafat AM, Hauser R, Braun JM. Paternal and maternal preconception urinary phthalate metabolite concentrations and child behavior. Environ Res. 2017;158:720-8.

74. Fox CW, Waddell KJ, Mousseau TA. Parental host-plant affects offspring lifehistories in a seed beetle. Ecology. 1995;76(2):402-11.

75. McNamara KB, Van Lieshout E, Simmons LW. The effect of maternal and paternal immune challenge on offspring immunity and reproduction in a cricket. J Evol Biol. 2014;27(6):1020-8.

76. Zirbel KE, Alto BW. Maternal and paternal nutrition in a mosquito influences offspring life histories but not infection with an arbovirus. Ecosphere. 2018; 9(10):e02469.

77. Li JH, Jiang DP, Wang YF, Yan JJ, Guo QY, Miao X, Lang HY, Xu SL, Liu JY, Guo GZ. Influence of electromagnetic pulse on the offspring sex ratio of male BALB/c mice. Environ Toxicol Pharmacol. 2017:54:155-61.

78. Klein SL, Schiebinger L, Stefanick ML, Cahill L, Danska J, de Vries GJ, Kibbe MR, McCarthy MM, Mogil JS, Woodruff TK, et al. Opinion: sex inclusion in basic research drives discovery. Proc Natl Acad Sci. 2015; 112(17):5257-8

79. Prendergast BJ, Onishi KG, Zucker I. Female mice liberated for inclusion in neuroscience and biomedical research. Neurosci Biobehav Rev. 2014; 40:1-5.

80. Masuyama H, Mitsui T, Eguchi T, Tamada S, Hiramatsu Y. The effects of paternal high-fat diet exposure on offspring metabolism with epigenetic changes in the mouse adiponectin and leptin gene promoters. Am J Physiol Endocrinol Metab. 2016;311(1):E236-45.

81. Naquiah MZF, James RJ, Suratman S, Lee LS, Hafidz MIM, Salleh MZ, Teh LK. Transgenerational effects of paternal heroin addiction on anxiety and aggression behavior in male offspring. Behav Brain Funct. 2016;12:23.

82. J. Marshall D, Uller T. When is a maternal effect adaptive? Oikos. 2007; 116(12):1957-63.

83. Crean AJ, Dwyer JM, Marshall DJ. Adaptive paternal effects? Experimental evidence that the paternal environment affects offspring performance. Ecology. 2013;94(11):2575-82.

84. Burgess SC, Marshall DJ. Adaptive parental effects: the importance of estimating environmental predictability and offspring fitness appropriately. Oikos. 2014;123(7):769-76.

85. Triantaphyllopoulos KA, Ikonomopoulos I, Bannister AJ. Epigenetics and inheritance of phenotype variation in livestock. Epigenetics Chromatin. 2016;9(1):31.

86. Bach À. Effects of nutrition and genetics on fertility in dairy cows. Reprod Fertil Dev. 2019;31(1):40-54.

87. Goddard ME, Whitelaw E. The use of epigenetic phenomena for the improvement of sheep and cattle. Front Genet. 2014;5:247.

88. Gerlinskaya LA, Maslennikova SO, Anisimova MV, Feofanova NA, Zavjalov EL, Kontsevaya GV, Moshkin YM, Moshkin MP. Modulation of embryonic development due to mating with immunised males. Reprod Fertil Dev. 2017;29(3):565-74

89. David I, Ricard A. A unified model for inclusive inheritance in livestock species. Genetics. 2019;212(4):1075-99.

90. Pachenari N, Azizi H, Ghasemi E, Azadi M, Semnanian S. Exposure to opiates in male adolescent rats alters pain perception in the male offspring. Behav Pharmacol. 2018;29:255-60.

91. Anderson LM, Riffle L, Wilson R, Travlos GS, Lubomirski MS, Alvord WG. Preconceptional fasting of fathers alters serum glucose in offspring of mice. Nutrition. 2006;22(3):327-31.
92. Voelkl B, Würbel H. Reproducibility crisis: are we ignoring reaction norms? Trends Pharmacol Sci. 2016:37(7):509-10.

93. Forstmeier W, Wagenmakers EJ, Parker TH. Detecting and avoiding likely false-positive findings - a practical guide. Biol Rev. 2017:92(4):1941-68.

94. Richter $\mathrm{SH}$. Systematic heterogenization for better reproducibility in animal experimentation. Lab Animal. 2017:46:343.

95. Bonduriansky R, Crean AJ, Day T. The implications of nongenetic inheritance for evolution in changing environments. Evol Appl. 2012;5(2):192-201.

96. Crean AJ, Marshall DJ. Coping with environmental uncertainty: dynamic bet hedging as a maternal effect. Philos Trans R Soc B Biol Sci. 2009;364(1520): 1087-96.

97. Cleasby IR, Nakagawa S. Neglected biological patterns in the residuals: a behavioural ecologist's guide to co-operating with heteroscedasticity. Behav Ecol Sociobiol. 2011;65(12):2361-72.

98. Nakagawa S, Poulin R, Mengersen K, Reinhold K, Engqvist L, Lagisz M, Senior AM. Meta-analysis of variation: ecological and evolutionary applications and beyond. Methods Ecol Evol. 2015;6(2):143-52.

99. Wilkins JF, Bhattacharya T. Intragenomic conflict over bet-hedging. Philos Trans R Soc B Biol Sci. 2019:374(1766):20180142.

100. Seebacher F, Krause J. Epigenetics of social behaviour. Trends Ecol Evol. 2019:34(9):818-30.

101. Charpentier MJE, Van Horn RC, Altmann J, Alberts SC. Paternal effects on offspring fitness in a multimale primate society. Proc Natl Acad Sci U S A. 2008;105(6):1988-92

102. Head ML, Berry LK, Royle NJ, Moore AJ. Paternal care: direct and indirect genetic effects of fathers on offspring performance. Evolution. 2012;66(11): 3570-81.

103. Braun K, Champagne FA. Paternal influences on offspring development: behavioural and epigenetic pathways. J Neuroendocrinol. 2014;26(10):697-706.

104. Abel EL. Paternal alcohol consumption: effects of age of testing and duration of paternal drinking in mice. Teratology. 1989;40(5):467-74.

105. Abel EL. Rat offspring sired by males treated with alcohol. Alcohol. 1993; 10(3):237-42.

106. Abel EL. Paternal alcohol exposure and hyperactivity in rat offspring: effects of amphetamine. Neurotoxicol Teratol. 1993;15(6):445-9.

107. Abel EL. Effects of physostigmine on male offspring sired by alcohol-treated fathers. Alcohol Clin Exp Res. 1994;18(3):648-52.

108. Abel EL. A surprising effect of paternal alcohol treatment on rat fetuses. Alcohol. 1995;12(1):1-6.

109. Abel EL, Bilitzke P. Paternal alcohol exposure: paradoxical effect in mice and rats. Psychopharmacology. 1990;100(2):159-64.

110. Abel EL, Moore C. Effects of paternal alcohol consumption in mice. Alcohol Clin Exp Res. 1987;11(6):533-5.

111. Abel EL, Tan SE. Effects of paternal alcohol consumption on pregnancy outcome in rats. Neurotoxicol Teratol. 1988;10(3):187-92.

112. Adler MI, Bonduriansky R. Paternal effects on offspring fitness reflect father's social environment. Evol Biol. 2013:40(2):288-92

113. Al-Juboori B, Hamdan F, Al-Salihi A. Paternal exposure to low-dose lead acetate: effect on implantation rate, pregnancy outcome, and sex ratio in mice. Turkish J Med Sci. 2016;46(3):936-41.

114. Alonso-Alvarez C, Bertr S, Sorci G. Sex-specific transgenerational effects of early developmental conditions in a passerine. Biol J Linn Soc. 2007;91(3): 469-74.

115. Assayed ME, Khalaf AA, Salem HA. Protective effects of garlic extract and vitamin $\mathrm{C}$ against in vivo cypermethrin-induced teratogenic effects in rat offspring. Food Chem Toxicol. 2010;48(11):3153-8.

116. Azadi M, Azizi H, Haghparast A. Paternal exposure to morphine during adolescence induces reward-resistant phenotype to morphine in male offspring. Brain Res Bull. 2019;147:124-32.

117. Baena-Diaz F, Martinez I, Gil-Perez Y, Gonzalez-Tokman D. Trans-generational effects of ivermectin exposure in dung beetles. Chemosphere. 2018;202:637-43.

118. Balasinor N, Gill-Sharma MK, Parte P, D'Souza S, Kedia N, Juneja HS. Effect of paternal administration of an antiestrogen, tamoxifen on embryo development in rats. Mol Cell Endocrinol. 2002;190(1):159-66.

119. Baste V, Moen BE, Oftedal G, Str LÅ, Bjørge L, Mild KH. Pregnancy outcomes after paternal radiofrequency field exposure aboard fast patrol boats. J Occup Environ Med. 2012;54(4):431-8

120. Bayoumy MH, Abou-Elnaga AM, Ghanim AA, Mashhoot GA. Egg cannibalism potential benefits for adult reproductive performance and offspring fitness of Coccinella undecimpunctata L. (Coleoptera: Coccinellidae). Egypt J Biol Pest Control. 2016;26(1):35-42. 
121. Beemelmanns $A$, Roth O. Biparental immune priming in the pipefish Syngnathus typhle. Zoology. 2016;119(4):262-72.

122. Beemelmanns A, Roth O. Grandparental immune priming in the pipefish Syngnathus typhle. BMC Evol Biol. 2017;17(1):1-15.

123. Bellve AR. Incorporation of [3H]uridine by mouse embryos with abnormalities induced by parental hyperthermia. Biol Reprod. 1976;15(5):632-46.

124. Beltrame D, Di Salle E, Giavini E, Gunnarsson K, Brughera M. Reproductive toxicity of exemestane, an antitumoral aromatase inactivator, in rats and rabbits. Reprod Toxicol. 2001;15(2):195-213.

125. Berk RS, Montgomery IN, Hazlett LD, Abel EL. Paternal alcohol consumption: effects on ocular response and serum antibody response to Pseudomonas aeruginosa infection in offspring. Alcohol Clin Exp Res. 1989;13(6):795-8.

126. Bieber AM, Marcon L, Hales BF, Robaire B. Effects of chemotherapeutic agents for testicular cancer on the male rat reproductive system, spermatozoa, and fertility. J Androl. 2006;27(2):189-200.

127. Bielawski DM, Abel EL. Acute treatment of paternal alcohol exposure produces malformations in offspring. Alcohol. 1997;14(4):397-401.

128. Bielawski DM, Zaher FM, Svinarich DM, Abel EL. Paternal alcohol exposure affects sperm cytosine methyltransferase messenger RNA levels. Alcohol Clin Exp Res. 2002;26(3):347-51.

129. Bohacek J, Farinelli M, Mirante O, Steiner G, Gapp K, Coiret G, Ebeling M, Durán-Pacheco G, Iniguez AL, Manuella F, et al. Pathological brain plasticity and cognition in the offspring of males subjected to postnatal traumatic stress. Mol Psychiatry. 2015;20(5):621-31.

130. Bondarenko LB, Shayakhmetova GM, Byshovets TF, Kovalenko VM. Pyrazinamide potential effects on male rats DNA fragmentation, bone type I collagen amino acid composition, reproductive capability and posterity antenatal and postnatal development. Acta Pol Pharm. 2012;69(5):843-50.

131. Bonduriansky R, Head M. Maternal and paternal condition effects on offspring phenotype in Telostylinus angusticollis (Diptera : Neriidae). J Evol Biol. 2007;20(6):2379-88.

132. Borges CDS, Pacheco TL, da Silva KP, Fernandes FH, Gregory M, Pupo AS, DMF S, Cyr DG, WDG K. Betamethasone causes intergenerational reproductive impairment in male rats. Reprod Toxicol. 2017;71:108-17.

133. Bramwell RK, McDaniel CD, Burke WH, Wilson JL, Howarth B. Influence of male broiler breeder dietary energy intake on reproduction and progeny growth. Poult Sci. 1996;75(6):767-75.

134. Brevik A, Lindeman B, Brunborg G, Duale N. Paternal benzo[a]pyrene exposure modulates microRNA expression patterns in the developing mouse embryo. Int J Cell Biol. 2012.

135. Bromfield JJ, Schjenken JE, Chin PY, Care AS, Jasper MJ, Robertson SA. Maternal tract factors contribute to paternal seminal fluid impact on metabolic phenotype in offspring. Proc Natl Acad Sci U S A. 2014;111(6): 2200-5.

136. Brown $\mathrm{KH}$, Schultz IR, Nagler JJ. Reduced embryonic survival in rainbow trout resulting from paternal exposure to the environmental estrogen $17 \mathrm{a}$ ethynylestradiol during late sexual maturation. Reproduction. 2007;134(5): 659-66

137. Buffett RF, Grace JT Jr, DiBerardino LA, Mir EA. Vertical transmission of murine leukemia virus. Cancer Res. 1969;29(3):588-95.

138. Burruel VR, Raabe OG, Overstreet JW, Wilson BW, Wiley LM. Paternal effects from methamidophos administration in mice. Toxicol Appl Pharmacol. 2000; 165(2):148-57.

139. Blakley PM, Kim JS, Firneisz GD. Effects of paternal subacute exposure to tordon 202C on fetal growth and development in CD-1 mice. Teratology. 1989;39(3):237-41.

140. Cahenzli F, Erhardt A. Transgenerational acclimatization in an herbivore-host plant relationship. Proc R Soc B Biol Sci. 2013;280:20122856.

141. Cake H, Lenzer I. On effects of paternal ethanol treatment on fetal outcome. Psychol Rep. 1985;57(1):51-7.

142. Callaghan BL, Cowan CSM, Richardson R. Treating generational stress: effect of paternal stress on development of memory and extinction in offspring is reversed by probiotic treatment. Psychol Sci. 2016;27(9):1171-80.

143. Campbell EJ, Flanagan JPM, Marchant NJ, Lawrence AJ. Reduced alcoholseeking in male offspring of sires exposed to alcohol self-administration followed by punishment-imposed abstinence. Pharmacol Res Perspect. 2018;6(2):e00384

144. Carbone P, Giordano F, Nori F, Mantovani A, Taruscio D, Lauria L, FigàTalamanca I. The possible role of endocrine disrupting chemicals in the aetiology of cryptorchidism and hypospadias: a population-based casecontrol study in rural Sicily. Int J Androl. 2007;30(1):3-13.
145. Ceccanti M, Coccurello R, Carito V, Ciafrè S, Ferraguti G, Giacovazzo G, Mancinelli R, Tirassa P, Chaldakov GN, Pascale E, et al. Paternal alcohol exposure in mice alters brain NGF and BDNF and increases ethanol-elicited preference in male offspring. Addict Biol. 2016;21(4):776-87.

146. Chang RC, Skiles WM, Chronister SS, Wang HQ, Sutton Gl, Bedi YS, Snyder $M$, Long CR, Golding MC. DNA methylation-independent growth restriction and altered developmental programming in a mouse model of preconception male alcohol exposure. Epigenetics. 2017;12(10):841-53.

147. Chang RC, Wang HQ, Bedi Y, Golding MC. Preconception paternal alcohol exposure exerts sex-specific effects on offspring growth and long-term metabolic programming. Epigenetics Chromatin. 2019;12:9.

148. Chen B, Li SQ, Ren Q, Tong XW, Zhang X, Kang L. Paternal epigenetic effects of population density on locust phase-related characteristics associated with heat-shock protein expression. Mol Ecol. 2015;24(4): 851-62.

149. Chen $\mathrm{THH}$, Chiu YH, Boucher BJ. Transgenerational effects of betel-quid chewing on the development of the metabolic syndrome in the Keelung Community-based Integrated Screening program. Am J Clin Nutr. 2006; 83(3):688-92.

150. Cheng RYS, Hockman T, Crawford E, Anderson LM, Shiao YH. Epigenetic and gene expression changes related to transgenerational carcinogenesis. Mol Carcinog. 2004;40(1):1-11.

151. Chowdhury SS, Lecomte V, Erlich JH, Maloney CA, Morris MJ. Paternal high fat diet in rats leads to renal accumulation of lipid and tubular changes in adult offspring. Nutrients. 2016:8:521.

152. Cicero TJ, Adams ML, Giordano A, Miller BT, O'Connor L, Nock B. Influence of morphine exposure during adolescence on the sexual maturation of male rats and the development of their offspring. J Pharmacol Exp Ther. 1991;256(3):1086-93.

153. Cicero TJ, Nock B, Oconnor L, Adams M, Meyer ER. Adverse-effects of paternal opiate exposure on offspring development and sensitivity to morphine-induced analgesia. J Pharmacol Exp Ther. 1995;273(1):386-92.

154. Cicero TJ, Nock B, O'Connor L, Adams ML, Sewing BN, Meyer ER. Acute alcohol exposure markedly influences male fertility and fetal outcome in the male rat. Life Sci. 1994;55(12):901-10.

155. Cicero TJ, Nock B, O'Connor LH, Sewing BN, Adams ML, Robert Meyer E. Acute paternal alcohol exposure impairs fertility and fetal outcome. Life Sci. 1994;55(2):PL33-6.

156. Cisse YM, Russart KLG, Nelson RJ. Parental exposure to dim light at night prior to mating alters offspring adaptive immunity. Sci Rep. 2017;7:1-10.

157. Cissé YM, Russart KLG, Nelson RJ. Depressive-like behavior is elevated among offspring of parents exposed to dim light at night prior to mating. Psychoneuroendocrinology. 2017;83:182-6.

158. Conforti S, Dietrich J, Kuhn T, van Koppenhagen N, Baur J, Rohner PT, Blanckenhorn WU, Schafer MA. Comparative effects of the parasiticide ivermectin on survival and reproduction of adult sepsid flies. Ecotoxicol Environ Saf. 2018;163:215-22.

159. Consitt LA, Saxena G, Slyvka Y, Clark BC, Friedl e M, Zhang YZ, Nowak FV. Paternal high-fat diet enhances offspring whole-body insulin sensitivity and skeletal muscle insulin signaling early in life. Physiol Rep. 2018;6(5):e13583.

160. Cooper-Willis CA, Olson JC, Brewer ME, Leslie GA. Influence of paternal immunity on idiotype expression in offspring. Immunogenetics. 1985; 21(1):1-10.

161. Cordero MI, Just N, Poirier GL, Sandi C. Effects of paternal and peripubertal stress on aggression, anxiety, and metabolic alterations in the lateral septum. Eur Neuropsychopharmacol. 2016;26(2):357-67.

162. Cordier S, Deplan F, ereau L, Hemon D. Paternal exposure to mercury and spontaneous abortions. Br J Ind Med. 1991;48(6):375-81.

163. Cortes JE, Abruzzese E, Chelysheva E, Guha M, Wallis N, Apperley JF. The impact of dasatinib on pregnancy outcomes. Am J Hematol. 2015;90(12):1111-5.

164. Crill WD, Huey RB, Gilchrist GW. Within- and between-generation effects of temperature on the morphology and physiology of Drosophila melanogaster. Evolution. 1996;50(3):1205-18.

165. Cropley JE, Eaton SA, Aiken A, Young PE, Giannoulatou E, Ho JWK, Buckl ME, Keam SP, Hutvagner G, et al. Male-lineage transmission of an acquired metabolic phenotype induced by grand-paternal obesity. Mol Metab. 2016; 5(8):699-708.

166. Csaba G, Karabélyos C. Transgenerational effect of a single neonatal benzpyrene treatment (imprinting) on the sexual behavior of adult female rats. Hum Exp Toxicol. 1997;16(10):553-6. 
167. da Cruz RS, Carney EJ, Clarke J, Cao H, Cruz MI, Benitez C, Jin L, Fu Y, Cheng $Z L$, Wang $Y$, et al. Paternal malnutrition programs breast cancer risk and tumor metabolism in offspring. Breast Cancer Res. 2018;20:99.

168. Daly HB, Stewart PW, Lunkenheimer L, Sargent D. Maternal consumption of Lake Ontario salmon in rats produces behavioral changes in tee offspring. Toxicol Ind Health. 1998;14(1):25-39.

169. Dawson BV, Robertson IGC, Wilson WR, Zwi LJ, Boys JT, Green AW. Evaluation of potential health effects of $10 \mathrm{kHz}$ magnetic fields: a rodent reproductive study. Bioelectromagnetics. 1998;19(3):162-71.

170. Dean A, van den Driesche S, Wang YL, McKinnell C, Macpherson S, Eddie SL, Kinnell H, Hurtado-Gonzalez P, Chambers TJ, Stevenson K, et al. Analgesic exposure in pregnant rats affects fetal germ cell development with intergenerational reproductive consequences. Sci Rep. 2016;6:19789.

171. Ding S, Fan Y, Zhao N, Yang H, Ye X, He D, Jin X, Liu J, Tian C, Li H, et al. High-fat diet aggravates glucose homeostasis disorder caused by chronic exposure to bisphenol A. J Endocrinol. 2014;221(1):167-79.

172. Ding TB, Mokshagundam S, Rinaudo PF, Osteen KG, Bruner-Tran KL. Paternal developmental toxicant exposure is associated with epigenetic modulation of sperm and placental Pgr and lgf2 in a mouse model. Biol Reprod. 2018; 99(4):864-76.

173. Dobrzyńska MM, Gajowik A, Radzikowska J, Tyrkiel EJ, Jankowska-Steifer EA. Male-mediated F1 effects in mice exposed to bisphenol A, either alone or in combination with X-irradiation. Mutat Res Genet Toxicol Environ Mutagen. 2015;789:36-45.

174. Dobrzyńska MM, Tyrkiel EJ, Pachocki KA. Developmental toxicity in mice following paternal exposure to di-N-butyl-phthalate (DBP). Biomed Environ Sci. 2011;24(5):569-78.

175. Duan MN, Xiong DQ, Bai X, Gao YL, Xiong YJ, Gao X, Ding GH. Transgenerational effects of heavy fuel oil on the sea urchin Strongylocentrotus intermedius considering oxidative stress biomarkers. Mar Environ Res. 2018;141:138-47.

176. Duan MN, Xiong DQ, Yang MY, Xiong YJ, Ding GH. Parental exposure to heavy fuel oil induces developmental toxicity in offspring of the sea urchin Strongylocentrotus intermedius. Ecotoxicol Environ Saf. 2018;159:109-19.

177. Ducatez S, Baguette M, Stevens VM, Legr D, Fréville H. Complex interactions between paternal and maternal effects: parental experience and age at reproduction affect fecundity and offspring performance in a butterfly. Evolution. 2012:66(11):3558-69.

178. Emanuele NV, LaPaglia N, Steiner J, Colantoni A, Van Thiel DH, Emanuele MA. Peripubertal paternal EtOH exposure: testicular oxidative injury, fecundity, and offspring. Endocrine. 2001;14(2):213-9.

179. Etterson JR, Galloway LF. The influence of light on paternal plants in Campanula americana (Campanulaceae): pollen characteristics and offspring traits. Am J Bot. 2002;89(12):1899-906.

180. Evans JP, Lymbery RA, Wiid KS, Rahman MM, Gasparini C. Sperm as moderators of environmentally induced paternal effects in a livebearing fish. Biol Lett. 2017;1313:20170087.

181. Falcão-Tebas F, Kuang J, Arceri C, Kerris JP, Andrikopoulos S, Marin EC, McConell GK. Four weeks of exercise early in life reprograms adult skeletal muscle insulin resistance caused by a paternal high-fat diet. J Physiol. 2019; 597(1):121-36.

182. Fan $Y$, Ding SB, Ye XL, Manyande A, He DL, Zhao NN, Yang HQ, Jin X, Liu J, et al. Does preconception paternal exposure to a physiologically relevant level of bisphenol A alter spatial memory in an adult rat? Horm Behav. 2013; 64(4):598-604.

183. Fan Y, Tian C, Liu QL, Zhen XY, Zhang H, Zhou LN, Li TBA, Zhang Y, Ding SB, $\mathrm{He} \mathrm{DL}$, et al. Preconception paternal bisphenol A exposure induces sexspecific anxiety and depression behaviors in adult rats. PLoS One. 2018; 13(2):e0192434.

184. Favero AM, Weis SN, Stangherlin EC, Rocha JBT, Nogueira CW. Sub-chronic exposure of adult male rats to diphenyl ditelluride did not affect the development of their progeny. Food Chem Toxicol. 2007;45(5):859-62

185. Favero AM, Weis SN, Stangherlin EC, Zeni G, Rocha JBT, Nogueira CW. Adult male rats sub-chronically exposed to diphenyl diselenide: effects on their progeny. Reprod Toxicol. 2007;23(1):119-23.

186. Feychting M, Floderus B, Ahlbom A. Parental occupational exposure to magnetic fields and childhood cancer (Sweden). Cancer Causes Control. 2000;11(2):151-6.

187. Finegersh A, Homanics GE. Paternal alcohol exposure reduces alcohol drinking and increases behavioral sensitivity to alcohol selectively in male offspring. PLoS One. 2014;9(6):e99078.
188. Fischer DK, Rice RC, Rivera AM, Donohoe M, Rajadhyaksha AM. Altered reward sensitivity in female offspring of cocaine-exposed fathers. Behav Brain Res. 2018;332:23-31.

189. Folger AT, Eismann EA, Stephenson NB, Shapiro RA, MacAluso M, Brownrigg ME, Gillespie RJ. Parental adverse childhood experiences and offspring development at 2 years of age. Pediatrics. 2018;141(4):e20172826.

190. Fontelles CC, Carney E, Clarke J, Nguyen NM, Yin C, Jin L, Cruz Ml, Ong TP, Hilakivi-Clarke L, De Assis S. Paternal overweight is associated with increased breast cancer risk in daughters in a mouse model. Sci Rep. 2016;6:28602.

191. Fontelles CC, Guido LN, Rosim MP, Andrade FO, Jin L, Inchauspe J, Pires VC, de Castro IA, Hilakivi-Clarke L, de Assis S, et al. Paternal programming of breast cancer risk in daughters in a rat model: opposing effects of animaland plant-based high-fat diets. Breast Cancer Res. 2016;18(1):71.

192. Fox CW, Bush ML, Wallin WG. Maternal age affects offspring lifespan of the seed beetle, Callosobruchus maculatus. Funct Ecol. 2003;17(6):811-20.

193. Friedman S, Larsen MD, Magnussen $B$, Jølving LR, de Silva P, Nørgård BM. Paternal use of azathioprine/6-mercaptopurine or methotrexate within 3 months before conception and long-term health outcomes in the offspring - a nationwide cohort study. Reprod Toxicol. 2017;73:196-200.

194. Fullston T, McPherson NO, Owens JA, Kang WX, eman LY, Lane M. Paternal obesity induces metabolic and sperm disturbances in male offspring that are exacerbated by their exposure to an "obesogenic" diet. Physiol Rep. 2015;3(3):e12336.

195. Fullston T, Teague EMCO, Palmer NO, Deblasio MJ, Mitchell M, Corbett M, Print CG, Owens JA, Lane M. Paternal obesity initiates metabolic disturbances in two generations of mice with incomplete penetrance to the F2 generation and alters the transcriptional profile of testis and sperm microRNA content. FASEB J. 2013;27(10):4226-43.

196. Futuyma DJ, Herrmann C, Milstein S, Keese MC. Apparent transgenerational effects of host plant in the leaf beetle Ophraella notulata (Coleoptera: Chrysomelidae). Oecologia. 1993;96(3):365-72.

197. Fort DJ, Stover EL, Bantle JA, Dumont JN, Finch RA. Evaluation of a reproductive toxicity assay using Xenopus laevis: boric acid, cadmium and ethylene glycol monomethyl ether. J Appl Toxicol. 2001;21(1):41-52.

198. Galloway LF. The effect of maternal and paternal environments on seed characters in the herbaceous plant Campanula americana (Campanulaceae). Am J Bot. 2001;88(5):832-40

199. Gapp K, Bohacek J, Grossmann J, Brunner AM, Manuella F, Nanni P, Mansuy IM. Potential of environmental enrichment to prevent transgenerational effects of paternal trauma. Neuropsychopharmacology. 2016;41(11):2749-58.

200. García-Palomares S, Navarro S, Pertusa JF, Hermenegildo C, GarcíaPérez MA, Rausell F, Cano A, Tarín JJ. Delayed fatherhood in mice decreases reproductive fitness and longevity of offspring. Biol Reprod. 2009;80(2):343-9.

201. Gasparini C, Dosselli R, Evans JP. Sperm storage by males causes changes in sperm phenotype and influences the reproductive fitness of males and their sons. Evol Lett. 2017:1(1):16-25.

202. Gasparini C, Lu CC, Dingemanse NJ, Tuni C. Paternal-effects in a terrestrial ectotherm are temperature dependent but no evidence for adaptive effects. Funct Ecol. 2018;32(4):1011-21.

203. Ghasemi N, Babaei H, Azizallahi S, Kheradm A. Effect of long-term administration of zinc after scrotal heating on mice spermatozoa and subsequent offspring quality. Andrologia. 2009;41(4):222-8.

204. Gilad T, Scharf I. Separation between maternal and paternal effects on offspring following exposure of adult red flour beetles to two stressors. Ecol Entomol. 2019;44:494-501.

205. Gill-Sharma MK, Balasinor N, Parte P, Aleem M, Juneja HS. Effects of tamoxifen metabolites on fertility of male rat. Contraception. 2001;63(2): 103-9.

206. Gomes J, Lloyd OL. Oral exposure of mice to formulations of organophosphorous pesticides: gestational and litter outcomes. Int J Environ Health Res. 2009;19(2):125-37.

207. González-Rojo S, Lombó M, Fernández-Díez C, Herráez MP. Male exposure to bisphenol a impairs spermatogenesis and triggers histone hyperacetylation in zebrafish testes. Environ Pollut. 2019;248:368-79.

208. Govic A, Penman J, Tammer AH, Paolini AG. Paternal calorie restriction prior to conception alters anxiety-like behavior of the adult rat progeny. Psychoneuroendocrinology. 2016;64:1-11.

209. Guillaume AS, Monro K, Marshall DJ. Transgenerational plasticity and environmental stress: do paternal effects act as a conduit or a buffer? Funct Ecol. 2016;30(7):1175-84. 
210. Halsey MJ, Green CJ, Monk SJ, Doré C, Knight JF, Luff NP. Maternal and paternal chronic exposure to enflurane and halothane: fetal and histological changes in the rat. Br J Anaesth. 1981;53(3):203-15.

211. Hammill KM, Fraz S, Lee AH, Wilson JY. The effects of parental carbamazepine and gemfibrozil exposure on sexual differentiation in zebrafish (Danio rerio). Environ Toxicol Chem. 2018;37(6):1696-706.

212. Harker A, Carroll C, Raza S, Kolb B, Gibb R. Preconception paternal stress in rats alters brain and behavior in offspring. Neuroscience. 2018;388:474-85.

213. Harker A, Raza S, Williamson K, Kolb B, Gibb R. Preconception paternal stress in rats alters dendritic morphology and connectivity in the brain of developing male and female offspring. Neuroscience. 2015;303:200-10.

214. Harris EP, Allardice HA, Schenk AK, Rissman EF. Effects of maternal or paternal bisphenol A exposure on offspring behavior. Horm Behav. 2018; 101:68-76.

215. Hazlett LD, Barrett RP, Berk RS, Abel EL. Maternal and paternal alcohol consumption increase offspring susceptibility to Pseudomonas aeruginosa ocular infection. Ophthalmic Res. 1989;21(5):381-7.

216. He F, Lidow IA, Lidow MS. Consequences of paternal cocaine exposure in mice. Neurotoxicol Teratol. 2006:28(2):198-209.

217. Hehar H, Ma I, Mychasiuk R. Intergenerational transmission of paternal epigenetic marks: mechanisms influencing susceptibility to post-concussion symptomology in a rodent model. Sci Rep. 2017;7:7171.

218. Hehar H, Yu K, Ma I, Mychasiuk R. Paternal age and diet: the contributions of a father's experience to susceptibility for post-concussion symptomology. Neuroscience. 2016;332:61-75.

219. Henkel AJ, Garner SR, Neff BD. Effects of paternal reproductive tactic on juvenile behaviour and kin recognition in Chinook salmon (Oncorhynchus tshawytscha). Ethology. 2011;117(5):451-8.

220. Hjollund NH, Bonde JP, Ernst E, Lindenberg S, Andersen AN, Olsen J. Pesticide exposure in male farmers and survival of in vitro fertilized pregnancies. Hum Reprod. 2004;19(6):1331-7.

221. Holson RR, Bates HK, LaBorde JB, Hansen DK. Behavioral teratology and dominant lethal evaluation of nitrous oxide exposure in rats. Neurotoxicol Teratol. 1995;17(5):583-92.

222. Horan TS, Marre A, Hassold T, Lawson C, Hunt PA. Germline and reproductive tract effects intensify in male mice with successive generations of estrogenic exposure. PLoS Genet. 2017;13(8):e1006980.

223. Hoyer C, Richter H, Br w C, Riva MA, Gass P. Preconceptional paternal exposure to a single traumatic event affects postnatal growth of female but not male offspring. NeuroReport. 2013;24(15):856-60.

224. Hrubec TC, Melin VE, Shea CS, Ferguson EE, Garofola C, Repine CM, Chapman TW, Patel HR, Razvi RM, Sugrue JE, et al. Ambient and dosed exposure to quaternary ammonium disinfectants causes neural tube defects in rodents. Birth Defects Res. 2017;109(14):1166-78.

225. Hwang SY, Kim WJ, Wee JJ, Choi JS, Kim SK. Panax ginseng improves survival and sperm quality in guinea pigs exposed to 2,3,7,8tetrachlorodibenzo-p-dioxin. BJU Int. 2004;94(4):663-8.

226. Ibn Lahmar Andaloussi Z, Taghzouti K, Abboussi O. Behavioural and epigenetic effects of paternal exposure to cannabinoids during adolescence on offspring vulnerability to stress. Int J Dev Neurosci. 2019;72:48-54.

227. Ishihara K, Warita K, Tanida T, Sugawara T, Kitagawa H, Hoshi N. Does paternal exposure to 2,3,7,8-tetrachlorodibenzo-p-dioxin (TCDD) affect the sex ratio of offspring? J Vet Med Sci. 2007;69(4):347-52.

228. Jamerson PA, Wulser MJ, Kimler BF. Neurobehavioral effects in rat pups whose sires were exposed to alcohol. Dev Brain Res. 2004;149(2):103-11.

229. Janecka M, uca A, Servadio M, Trezza V, Smith R, Mill J, Schalkwyk LC, Reichenberg A, Fern e C. Effects of advanced paternal age on trajectories of social behavior in offspring. Genes Brain Behav. 2015;14(6):443-53.

230. Ju LS, Yang JJ, Morey TE, Gravenstein N, Seubert CN, Resnick JL, Zhang JQ, Martynyuk AE. Role of epigenetic mechanisms in transmitting the effects of neonatal sevoflurane exposure to the next generation of male, but not female, rats. Br J Anaesth. 2018;121(2):406-16.

231. Jonsson $B$, Jonsson N. Trans-generational maternal effect: temperature influences egg size of the offspring in Atlantic salmon Salmo salar. J Fish Biol. 2016;89(2):1482-7.

232. Kamarzaman S, Abdul Wahab AY, Abdul Rahman S. Effects of thymoquinone supplementation on cyclophosphamide toxicity of mouse embryo in vitro. Glob Vet. 2014;12(1):80-90.

233. Kangassalo K, Valtonen TM, Roff D, Pölkki M, Dubovskiy IM, Sorvari J, Rantala MJ. Intra- and trans-generational effects of larval diet on susceptibility to an entomopathogenic fungus, Beauveria bassiana, in the greater wax moth, Galleria mellonella. J Evol Biol. 2015;28(8):1453-64.

234. Kaufmann J, Lenz TL, Milinski M, Eizaguirre C. Experimental parasite infection reveals costs and benefits of paternal effects. Ecol Lett. 2014;17(11):1409-17.

235. Kedia N, Gill-Sharma MK, Parte P, Juneja HS, Balasinor N. Effect of paternal tamoxifen on the expression of insulin-like growth factor 2 and insulin-like growth factor type 1 receptor in the post-implantation rat embryos. Mol Reprod Dev. 2004;69(1):22-30.

236. Kedia-Mokashi N, Makawy AEL, Saxena M, Balasinor NH. Chromosomal aberration in the post-implantation embryos sired by tamoxifen treated male rats. Mutat Res Genet Toxicol Environ Mutagen. 2010;703(2):169-73.

237. Kedia-Mokashi NA, Kadam L, Ankolkar M, Dumasia K, Balasinor NH. Aberrant methylation of multiple imprinted genes in embryos of tamoxifen-treated male rats. Reproduction. 2013;146(2):155-68.

238. Kedia-Mokashi NA, Mugasimangalam R, Aiyaz M, Mukherjee S, Balasinor NH. Aberrant expression of imprinted genes in post-implantation rat embryos. Life Sci. 2011;88(13):634-43.

239. Kelly TL, Li E, Trasler JM. 5-Aza-2'-deoxycytidine induces alterations in murine spermatogenesis and pregnancy outcome. J Androl. 2003;24(6):822-30.

240. Khalili L, Gholami S, Ansari-Lari M. Evaluation of offspring sex ratio, sex hormones and antioxidant enzymes following exposure to methyl tertiary butyl ether in adult male Sprague-Dawley rats. EXCLI J. 2015;14:75-82.

241. Kieseier BC, Benamor M. Pregnancy outcomes following maternal and paternal exposure to teriflunomide during treatment for relapsing-remitting multiple sclerosis. Neurol Ther. 2014;3(2):133-8.

242. Killinger CE, Robinson S, Stanwood GD. Subtle biobehavioral effects produced by paternal cocaine exposure. Synapse. 2012;66(10):902-8.

243. Kim P, Choi CS, Park JH, Joo SH, Kim SY, Ko HM, Kim KC, Jeon SJ, Park SH, Han $\mathrm{SH}$, et al. Chronic exposure to ethanol of male mice before mating produces attention deficit hyperactivity disorder-like phenotype along with epigenetic dysregulation of dopamine transporter expression in mouse offspring. J Neurosci Res. 2014:92(5):658-70.

244. Kinnally EL, Capitanio JP. Paternal early experiences influence infant development through non-social mechanisms in Rhesus Macaques. Front Zool. 2015;12(Suppl 1):S14.

245. Kinnally EL, Gonzalez MN, Capitanio JP. Paternal line effects of early experiences persist across three generations in rhesus macaques. Dev Psychobiol. 2018;60(8):879-88.

246. Knezovich JG, Ramsay M. The effect of preconception paternal alcohol exposure on epigenetic remodeling of the $\mathrm{H} 19$ and Rasgrf1 imprinting control regions in mouse offspring. Front Genet. 2012;3:10.

247. Kolasa-Wolosiuk A, Misiakiewicz-Has K, Baranowska-Bosiacka I, Gutowska I, Wiszniewska B. Androgen levels and apoptosis in the testis during postnatal development of finasteride-treated male rat offspring. Folia Histochem Cytobiol. 2015;53(3):236-48.

248. Korgan AC, O'Leary E, Bauer J, Fortier A, Weaver ICG, Perrot TS. Effects of paternal predation risk and rearing environment on maternal investment and development of defensive responses in the offspring. eNeuro. 2016;3(6): e0231-16.2016.

249. Korgan AC, O'Leary E, King JL, Weaver ICG, Perrot TS. Effects of paternal high-fat diet and rearing environment on maternal investment and development of defensive responses in the offspring Psychoneuroendocrinology. 2018;91:20-30.

250. Kyjovska ZO, Boisen AMZ, Jackson P, Wallin H, Vogel U, Hougaard KS. Daily sperm production: application in studies of prenatal exposure to nanoparticles in mice. Reprod Toxicol. 2013;36:88-97.

251. Lacey EP. Parental effects in Plantago lanceolata L. 1. A growth chamber experiment to examine pre- and postzygotic temperature effects. Evolution. 1996;50(2):865-78

252. Lafont M, Goncalves P, Guo X, Montagnani C, Raftos D, Green T. Transgenerational plasticity and antiviral immunity in the Pacific oyster (Crassostrea gigas) against Ostreid herpesvirus 1 (OsHV-1). Dev Comp Immunol. 2019;91:17-25.

253. Lam MKP, Homewood J, Taylor AJ, Mazurski EJ. Second generation effects of maternal alcohol consumption during pregnancy in rats. Prog NeuroPsychopharmacol Biol Psychiatry. 2000;24(4):619-31.

254. Lamb JCl, Moore JA, Marks TA, Haseman JK. Development and viability of offspring of male mice treated with chlorinated phenoxy acids and 2, 3, 7 , 8-tetrachlorodibenzo-p-dioxin. J Toxicol Environ Health. 1981;8(5):835-44.

255. Lawson CC, Schnorr TM, Whelan EA, Deddens JA, Dankovic DA, Piacitelli LA, Sweeney MH, Connally LB. Paternal occupational exposure to 2,3,7,8- 
tetrachlorodibenzo-p-dioxin and birth outcomes of offspring: birth weight, preterm delivery, and birth defects. Environ Health Perspect. 2004;112(14): 1403-8.

256. Le Cornet C, Fervers B, Pukkala E, Tynes T, Feychting M, Hansen J, Togawa K, Nordby KC, Dalton SO, Uuksulainen S, et al. Parental occupational exposure to organic solvents and testicular germ cell tumors in their offspring: NORDTEST study. Environ Health Perspect. 2017;125(6):067023.

257. Leão VF, Raimundo JM, Ferreira LLDM, Santos-Silva JC, Vettorazzi JF, Bonfleur ML, Carneiro EM, Ribeiro RA. Effects of paternal hypothalamic obesity and taurine supplementation on adiposity and vascular reactivity in rat offspring. Adv Exp Med Biol. 2015;803:749-63.

258. Lecomte V, Maloney CA, Wang KW, Morris MJ. Effects of paternal obesity on growth and adiposity of male rat offspring. Am J Physiol Endocrinol Metab. 2017;312(2):E117-25

259. Ledig M, Misslin R, Vogel E, Holownia A, Copin JC, Tholey G. Paternal alcohol exposure: developmental and behavioral effects on the offspring of rats. Neuropharmacology. 1998;37(1):57-66.

260. Lee S, Lee MS, Park J, Zhang JY, Jin DI. Oxidative stress in the testis induced by tamoxifen and its effects on early embryo development in isogenic mice. J Toxicol Sci. 2012;37(4):675-9.

261. Leite GAA, Fiqueiredo TM, Guerra MT, Borges CDS, Fern e FH, AnselmoFranci JA, Kempinas WDG. Ascorbic acid co-administered with rosuvastatin reduces reproductive impairment in the male offspring from male rats exposed to the statin at pre-puberty. Food Chem Toxicol. 2018;118:416-29.

262. Leite GAA, Figueiredo TM, Pacheco TL, Guerra MT, Anselmo-Franci JA, Kempinas WDG. Reproductive outcomes in rat female offspring from male rats co-exposed to rosuvastatin and ascorbic acid during pre-puberty. J Toxicol Environ Health A Curr Issues. 2018;81(17):873-92.

263. Levine SZ, Levav I, Pugachova I, Yoffe R, Becher Y. Transgenerational effects of genocide exposure on the risk and course of schizophrenia: a population-based study. Schizophr Res. 2016;176(2):540-5.

264. Li CQ, Luo YW, Bi FF, Cui TT, Song L, Cao WY, Zhang JY, Li F, Xu JM, Hao W, et al. Development of anxiety-like behavior via hippocampal IGF-2 signaling in the offspring of parental morphine exposure: effect of enriched environment. Neuropsychopharmacology. 2014;39(12):2777-87.

265. Li J, Liu S, Li S, Feng R, Na L, Chu X, Wu X, Niu Y, Sun Z, Han T, et al. Prenatal exposure to famine and the development of hyperglycemia and type 2 diabetes in adulthood across consecutive generations: a population-based cohort study of families in Suihua, China. Am J Clin Nutr. 2017;105(1):221-7

266. Li J, Lu YP, Tsuprykov O, Hasan AA, Reichetzeder C, Tian M, Zhang XL, Zhang Q, Sun GY, Guo JL, et al. Folate treatment of pregnant rat dams abolishes metabolic effects in female offspring induced by a paternal preconception unhealthy diet. Diabetologia. 2018;61(8):1862-76.

267. Li J, Na L, Ma H, Zhang Z, Li T, Lin L, Li Q, Sun C, Li Y. Multigenerational effects of parental prenatal exposure to famine on adult offspring cognitive function. Sci Rep. 2015:5:13792.

268. Li X, Shi X, Hou Y, Cao X, Gong L, Wang H, Li J, Li J, Wu C, Xiao D, et al. Paternal hyperglycemia induces transgenerational inheritance of susceptibility to hepatic steatosis in rats involving altered methylation on Ppara promoter. Biochim Biophys Acta Mol basis Dis. 2019;1865(1):147-60.

269. Li Y, Liu L, Wang B, Xiong J, Li Q, Wang J, Chen D. Impairment of reproductive function in a male rat model of non-alcoholic fatty liver disease and beneficial effect of $\mathrm{N}-3$ fatty acid supplementation. Toxicol Lett. 2013;222(2):224-32.

270. Liang F, Diao L, Jiang N, Zhang J, Wang HJ, Zhou WH, Huang GY, Ma D. Chronic exposure to ethanol in male mice may be associated with hearing loss in offspring. Asian J Androl. 2015;17(6):985-90.

271. Liang F, Diao L, Liu J, Jiang N, Zhang J, Wang HJ, Zhou WH, Huang GY, Ma D. Paternal ethanol exposure and behavioral abnormities in offspring: associated alterations in imprinted gene methylation. Neuropharmacology. 2014:81:126-33.

272. Little BB, Rigsby CH, Little LR. Pilot and astronaut offspring: possible G-force effects on human sex ratio. Aviat Space Environ Med. 1987:58(7):707-9.

273. Livy DJ, Maier SE, West JR. Long-term alcohol exposure prior to conception results in lower fetal body weights. Birth Defects Res B Dev Reprod Toxicol. 2004;71(3):135-41.

274. Logue JN, Hamburger S, Silverman PM, Chiacchierini RP. Congenital anomalies and paternal occupational exposure to shortwave, microwave, infrared, and acoustic radiation. J Occup Med. 1985:27(6):451-2.
275. Lombó M, Fernández-Díez C, González-Rojo S, Navarro C, Robles V, Herráez MP. Transgenerational inheritance of heart disorders caused by paternal bisphenol A exposure. Environ Pollut. 2015;206:667-78.

276. Luo GY, Wei RF, Wang SL, Wang JD. Paternal bisphenol a diet changes prefrontal cortex proteome and provokes behavioral dysfunction in male offspring. Chemosphere. 2017;184:720-9.

277. Lutwak-Mann C. Observations on progeny of thalidomide-treated male rabbits. Br Med J. 1964;1(5390):1090-1.

278. Ly L, Chan D, Aarabi M, ry M, Behan NA, MacFarlane AJ, Trasler J. Intergenerational impact of paternal lifetime exposures to both folic acid deficiency and supplementation on reproductive outcomes and imprinted gene methylation. Mol Hum Reprod. 2017;23(7):461-77.

279. Magiafoglou A, Hoffmann AA. Cross-generation effects due to cold exposure in Drosophila serrata. Funct Ecol. 2003;17(5):664-72.

280. Mankes RF, Lefevre R, Benitz KF, Rosenblum I, Bates H, Walker AIT, Abraham $\mathrm{R}$, Rockwood W. Paternal effects of ethanol in the Long-Evans rat. J Toxicol Environ Health. 1982;10(6):871-8.

281. Manners MT, Yohn NL, Lahens NF, Grant GR, Bartolomei MS, Blendy JA. Transgenerational inheritance of chronic adolescent stress: effects of stress response and the amygdala transcriptome. Genes Brain Behav. 2019;18: e12493.

282. Mao Z, Xia W, Chang H, Huo W, Li Y, Xu S. Paternal BPA exposure in early life alters lgf2 epigenetic status in sperm and induces pancreatic impairment in rat offspring. Toxicol Lett. 2015;238(3):30-8.

283. Maselli J, Hales BF, Robaire B. The effects of chemotherapy with bleomycin, etoposide, and cis-platinum (BEP) on rat sperm chromatin remodeling, fecundity and testicular gene expression in the progeny. Biol Reprod. 2013; 89(4):85,1-9.

284. Mashoodh R, Franks B, Curley JP, Champagne FA. Paternal social enrichment effects on maternal behavior and offspring growth. Proc Natl Acad Sci U S A. 2012;109:17232-8

285. McConaha ME, Ding T, Lucas JA, Arosh JA, Osteen KG, Bruner-Tran KL. Preconception omega-3 fatty acid supplementation of adult male mice with a history of developmental 2,3,7,8-tetrachlorodibenzo-p-dioxin exposure prevents preterm birth in unexposed female partners. Reproduction. 2011;142(2):235-41.

286. McCoy CR, Jackson NL, Brewer RL, Moughnyeh MM, Smith DL Jr, Clinton SM. A paternal methyl donor depleted diet leads to increased anxiety- and depression-like behavior in adult rat offspring. Biosci Rep. 2018; 38BSR20180730

287. McPherson NO, Bell VG, er-Fox DL, Fullston T, Wu LL, Robker RL, Lane M. When two obese parents are worse than one! Impacts on embryo and fetal development. Am J Physiol Endocrinol Metab. 2015;309(6):E568-81.

288. Meek LR, Myren K, Sturm J, Burau D. Acute paternal alcohol use affects offspring development and adult behavior. Physiol Behav. 2007;91(1): 154-60.

289. Mega F, de Meireles ALF, Piazza FV, Spindler C, Segabinazi E, Salvalaggio GD, Achaval M, Marcuzzo S. Paternal physical exercise demethylates the hippocampal DNA of male pups without modifying the cognitive and physical development. Behav Brain Res. 2018;348:1-8.

290. Michaud JP, Bista M, Mishra G, Singh O. Sexual activity diminishes male virility in two Coccinella species: consequences for female fertility and progeny development. Bull Entomol Res. 2013;103(5):570-7.

291. Miersch C, Döring F. Paternal dietary restriction affects progeny fat content in Caenorhabditis elegans. IUBMB Life. 2012;64(7):644-8.

292. Mirhosseini MA, Michaud JP, Jalali MA, Ziaaddini M. Paternal effects correlate with female reproductive stimulation in the polyandrous ladybird Cheilomenes sexmaculata. Bull Entomol Res. 2014;104(4):480-5.

293. Mitchell M, Strick R, Strissel PL, Dittrich R, McPherson NO, Lane M, Pliushch G, Potabattula R, Haaf T, El Hajj N. Gene expression and epigenetic aberrations in F1-placentas fathered by obese males. Mol Reprod Dev. 2017; 84(4):316-28

294. Mjøen G, Sætre DO, Lie RT, Tynes T, Blaasaas KG, Hannevik M, Irgens LM Paternal occupational exposure to radiofrequency electromagnetic fields and risk of adverse pregnancy outcome. Eur J Epidemiol. 2006;21(7):529-35.

295. Morgan CP, Bale TL. Early prenatal stress epigenetically programs dysmasculinization in second-generation offspring via the paternal lineage. J Neurosci. 2011;31(33):11748-55.

296. Murashov AK, Pak ES, Koury M, Ajmera A, Jeyakumar M, Parker M, Williams O, Ding J, Walters D, Neufer PD. Paternal long-term exercise programs 
offspring for low energy expenditure and increased risk for obesity in mice. FASEB J. 2016;30(2):775-84.

297. Mychasiuk R, Harker A, Inytskyy S, Gibb R. Paternal stress prior to conception alters DNA methylation and behaviour of developing rat offspring. Neuroscience. 2013;241:100-5.

298. Mychasiuk R, Zahir S, Schmold N, Inytskyy S, Kovalchuk O, Gibb R. Parental enrichment and offspring development: modifications to brain, behavior and the epigenome. Behav Brain Res. 2012;228(2):294-8.

299. Nelson BK, Brightwell WS, Burg JR, Massari VJ. Behavioral and neurochemical alterations in the offspring of rats after maternal or paternal inhalation exposure to the industrial solvent 2-methoxyethanol. Pharmacol Biochem Behav. 1984;20(2):269-79.

300. Nelson BK, Brightwell WS, MacKenzie-Taylor DR, Burg JR, Massari VJ. Neurochemical, but not behavioral, deviations in the offspring of rats following prenatal or paternal inhalation exposure to ethanol. Neurotoxicol Teratol. 1988;10(1):15-22.

301. Nelson BK, Brightwell WS, Robertson SK, Khan A, Krieg EF Jr, Massari VJ. Behavioral teratology investigation of 1-butanol in rats. Neurotoxicol Teratol. 1989;11(3):313-5.

302. Niknazar S, Nahav i A, Peyv i AA, Peyv i H, Roozbahany NA, Abbaszadeh HA. Hippocampal NR3C1 DNA methylation can mediate part of preconception paternal stress effects in rat offspring. Behav Brain Res. 2017;324:71-6.

303. Noguera JC, Metcalfe NB, Monaghan P. Experimental demonstration that offspring fathered by old males have shorter telomeres and reduced lifespans. Proc R Soc B Biol Sci. 2018;285:20180268.

304. Nygaard UC, Hansen JS, Groeng EC, Melkild I, Løvik M. Suppression of allergen-specific IgE in offspring after preconceptional immunisation: maternal, paternal and genetic influences. Scand J Immunol. 2013;77(2): 92-103.

305. Oakes DJ, Webster WS, Brown-Woodman PDC, Ritchie HE. A study of the potential for a herbicide formulation containing 2,4-D and picloram to cause male-mediated developmental toxicity in rats. Toxicol Sci. 2002;68(1): 200-6.

306. Ornellas F, Bringhenti I, Mattos BANF, arim-de-Lacerda CA, Aguila MB. Father's obesity programs the adipose tissue in the offspring via the local renin-angiotensin system and MAPKs pathways, especially in adult male mice. Eur J Nutr. 2018;57(5):1901-12.

307. O'Neill SM, Hallford DM. Semen characteristics, mating performance and serum testosterone in rams fed sewage solids. Theriogenology. 1985;24(1):21-33.

308. Park HS, Kim TW. Paternal physical exercise improves spatial learning ability by enhancing hippocampal neuroplasticity in male pups born from obese maternal rats. J Exerc Rehabil. 2017;13(3):266-72.

309. Pataia V, Papacleovoulou G, Nikolova V, Samuelsson AM, Chambers S, Jansen E, Taylor PD, Poston L, Williamson C. Paternal cholestasis exacerbates obesity-associated hypertension in male offspring but is prevented by paternal ursodeoxycholic acid treatment. Int J Obes. 2019;43(2):319-30

310. Pauwels S, Truijen I, Ghosh M, Duca RC, Langie SAS, Bekaert B, Freson K, Huybrechts I, Koppen G, Devlieger R, et al. The effect of paternal methylgroup donor intake on offspring DNA methylation and birth weight. J Dev Orig Health Dis. 2017;8(3):311-21.

311. Pecori C, Giannini M, Portaccio E, Ghezzi A, Hakiki B, Pastò L, Razzolini L, Sturchio A, De Giglio L, Pozzilli C, et al. Paternal therapy with disease modifying drugs in multiple sclerosis and pregnancy outcomes: a prospective observational multicentric study. BMC Neurol. 2014;14:114.

312. Petropoulos S, Matthews SG, Szyf M. Adult glucocorticoid exposure leads to transcriptional and DNA methylation changes in nuclear steroid receptors in the hippocampus and kidney of mouse male offspring. Biol Reprod. 2014; 90(2):43.

313. Phillips NE, Rouchon AM. A dose-dependent relationship between copper burden in female urchin gonads and developmental impairment of their offspring. Mar Environ Res. 2018;136:120-5.

314. Piña-Guzmán B, Sánchez-Gutiérrez M, Marchetti F, Hernández-Ochoa I, SolísHeredia MJ, Quintanilla-Vega B. Methyl-parathion decreases sperm function and fertilization capacity after targeting spermatocytes and maturing spermatozoa. Toxicol Appl Pharmacol. 2009;238(2):141-9.

315. Pitt JA, Trevisan R, Massarsky A, Kozal JS, Levin ED, Di Giulio RT. Maternal transfer of nanoplastics to offspring in zebrafish (Danio rerio): a case study with nanopolystyrene. Sci Total Environ. 2018;643:324-34.

316. Potashnik G, Phillip M. Lack of birth defects among offspring conceived during or after paternal exposure to dibromochloropropane (DBCP). Andrologia. 1988;20(1):90-4.
317. Prasad MH, Pushpavathi K, Devi GS, Reddy PP. Reproductive epidemiology in sulfonamide factory workers. J Toxicol Environ Health. 1996;47(2):109-14.

318. Priest NK, Mackowiak B, Promislow DEL. The role of parental age effects on the evolution of aging. Evolution. 2002;56(5):927-35.

319. Rahman SA, Samat NHA, Ahmad NA, Abdullah AR, Zahri SM, Kamarzaman S. Investigating the potential of Nigella sativa and thymoquinone in salvaging the embryo from effects of toxic paternal exposure to cyclophosphamide. Int Med J Malays. 2017;16(1):99-106.

320. Ricci E, Noli S, Cipriani S, La Vecchia I, Chiaffarino F, Ferrari S, Mauri PA, Reschini M, Fedele L, Parazzini F. Maternal and paternal caffeine intake and ART outcomes in couples referring to an Italian fertility clinic: a prospective cohort. Nutrients. 2018;10(8):1116.

321. Robledo CA, Yeung E, Mendola P, Sundaram R, Maisog J, Sweeney AM, Barr DB, Buck Louis GM. Preconception maternal and paternal exposure to persistent organic pollutants and birth size: the LIFE study. Environ Health Perspect. 2015;123(1):88-94.

322. Rompala GR, Finegersh A, Homanics GE. Paternal preconception ethanol exposure blunts hypothalamic-pituitary-adrenal axis responsivity and stressinduced excessive fluid intake in male mice. Alcohol. 2016:53:19-25.

323. Rompala GR, Finegersh A, Slater M, Homanics GE. Paternal preconception alcohol exposure imparts intergenerational alcoholrelated behaviors to male offspring on a pure C57BL/6J background. Alcohol. 2017;60:169-77.

324. Roth O, Joop G, Eggert H, Hilbert J, Daniel J, Schmid-Hempel P, Kurtz J. Paternally derived immune priming for offspring in the red flour beetle, Tribolium castaneum. J Anim Ecol. 2010;79(2):403-13.

325. Roth O, Klein V, Beemelmanns A, Scharsack JP, Reusch TBH. Male pregnancy and biparental immune priming. Am Nat. 2012;180(6):802-14.

326. Ryan DP, Henzel KS, Pearson BL, Siwek ME, Papazoglou A, Guo L, Paesler K, Yu M, Müller R, Xie K, et al. A paternal methyl donor-rich diet altered cognitive and neural functions in offspring mice. Mol Psychiatry. 2018;23(5): $1345-55$.

327. Rawat A, Guo J, Renoir T, Pang TY, Hannan AJ. Hypersensitivity to sertraline in the absence of hippocampal 5-HT1AR and 5-HTT gene expression changes following paternal corticosterone treatment. Environ Epigenetics. 2018:4(2):dvy015.

328. Santavirta T, Santavirta N, Gilman SE. Association of the World War II Finnish evacuation of children with psychiatric hospitalization in the next generation. JAMA Psychiatry. 2018;75(1):21-7.

329. Schade FM, Clemmesen C, Wegner KM. Within- and transgenerational effects of ocean acidification on life history of marine three-spined stickleback (Gasterosteus aculeatus). Mar Biol. 2014;161(7):1667-76.

330. Schmid B, Dolt C. Effects of maternal and paternal environment and genotype on offspring phenotype in Solidago altissima L. Evolution. 1994; 48(5):1525-49.

331. Schnorr TM, Lawson CC, Whelan EA, Dankovic DA, Deddens JA, Piacitelli LA, Reefhuis J, Sweeney MH, Connally LB, Fingerhut MA. Spontaneous abortion, sex ratio, and paternal occupational exposure to 2,3,7,8-tetrachlorodibenzop-dioxin. Environ Health Perspect. 2001;109(11):1127-32.

332. Seethalakshmi L, Flores C, Kinkead T, Carboni AA, Malhotra RK, Menon M. Effects of subchronic treatment with cis-platinum on testicular function, fertility, pregnancy outcome, and progeny. J Androl. 1992;13(1):65-74.

333. Sellin MK, Eidem TM, Kolok AS. Cadmium exposures in fathead minnows: are there sex-specific differences in mortality, reproductive success, and $\mathrm{Cd}$ accumulation? Arch Environ Contam Toxicol. 2007;52(4):535-40.

334. Serre V, Robaire B. Paternal age affects fertility and progeny outcome in the Brown Norway rat. Fertil Steril. 1998;70(4):625-31.

335. Shama LNS, Wegner KM. Grandparental effects in marine sticklebacks: transgenerational plasticity across multiple generations. J Evol Biol. 2014; 27(11):2297-307.

336. Shi X, Li X, Hou Y, Cao X, Zhang Y, Wang H, Wang H, Peng C, Li J, Li Q, et al. Paternal hyperglycemia in rats exacerbates the development of obesity in offspring. J Endocrinol. 2017;234(2):175-86.

337. Shiao YH, Leighty RM, Wang C, Ge X, Crawford EB, Spurrier JM, McCann SD, Fields $J R$, Fornwald L, Riffle L, et al. Ontogeny-driven rDNA rearrangement, methylation, and transcription, and paternal influence. PLoS One. 2011;6(7):e22266.

338. Shim YK, Miynarek SP, van Wijngaarden E. Parental exposure to pesticides and childhood brain cancer: U.S. Atlantic Coast Childhood Brain Cancer Study. Environ Health Perspect. 2009;117(6):1002-6.

339. Short AK, Fennell KA, Perreau VM, Fox A, O'Bryan MK, Kim JH, Bredy TW, Pang TY, Hannan AJ. Elevated paternal glucocorticoid exposure alters the 
small noncoding RNA profile in sperm and modifies anxiety and depressive phenotypes in the offspring. Transl Psychiatry. 2016;6:e837.

340. Short AK, Yeshurun S, Powell R, Perreau VM, Fox A, Kim JH, Pang TY, Hannan AJ. Exercise alters mouse sperm small noncoding RNAs and induces a transgenerational modification of male offspring conditioned fear and anxiety. Transl Psychiatry. 2017;7(5):e1114.

341. Shu XO, Stewart P, Wen WQ, Han DH, Potter JD, Buckley JD, Heineman E, Robison LL. Parental occupational exposure to hydrocarbons and risk of acute lymphocytic leukemia in offspring. Cancer Epidemiol Biomark Prev. 1999;8(9):783-91.

342. Silva PVE, da Silva RF, Borges CD, Cavariani MM, Francia C, Barbosa F, Kempinas WD. Sexual differentiation and reproductive development of female rat offspring after paternal exposure to the anti-tumor pharmaceutical cisplatin. Reprod Toxicol. 2016;60:112-22.

343. Smith RG, Fernandes C, Kember R, Schalkwyk LC, Buxbaum J, Reichenberg A, Mill J. Transcriptomic changes in the frontal cortex associated with paternal age. Mol Autism. 2014;5:24.

344. Smith RG, Kember RL, Mill J, Fernandes C, Schalkwyk LC, Buxbaum JD, Reichenberg A. Advancing paternal age is associated with deficits in social and exploratory behaviors in the offspring: a mouse model. PLoS One. 2009:4(12):e8456.

345. Soubry A, Murphy SK, Wang F, Huang Z, Vidal AC, Fuemmeler BF, Kurtzberg J, Murtha A, Jirtle RL, Schildkraut JM, et al. Newborns of obese parents have altered DNA methylation patterns at imprinted genes. Int J Obes. 2015;39(4):650-7.

346. Soyka LF, Joffe JM, Peterson JM, Smith SM. Chronic methadone administration to male rats: tolerance to adverse effects on sires and their progeny. Pharmacol Biochem Behav. 1978;9(4):405-9.

347. Soyka LF, Peterson JM, Joffe JM. Lethal and sublethal effects on the progeny of male rats treated with methadone. Toxicol Appl Pharmacol. 1978;45(3):797-807.

348. Spindler C, Segabinazi E, de Meireles ALF, Piazza FY, Mega F, Salvalaggio GD, Achava M, Elsner VR, Marcuzzo S. Paternal physical exercise modulates global DNA methylation status in the hippocampus of male rat offspring. Neural Regen Res. 2018;14(3):491-500.

349. Steele EJ. Observations on offspring of mice made diabetic with streptozocin. Diabetes. 1988;37(8):1035-43.

350. Tang CK, Chalon J, Markham JP, Ramanathan S, Turndorf H. Exposure of sires to enflurane affects learning function of murine progeny. Anesth Analg. 1984;63(8):729-30.

351. Terashima M, Barbour S, Ren J, Yu W, Han Y, Muegge K. Effect of high fat diet on paternal sperm histone distribution and male offspring liver gene expression. Epigenetics. 2015;10(9):161-71.

352. Tornqvist S. Paternal work in the power industry: effects on children at delivery. J Occup Environ Med. 1998;40(2):111-7.

353. Triggs AM, Knell RJ. Parental diet has strong transgenerational effects on offspring immunity. Funct Ecol. 2012;26(6):1409-17.

354. Ueker ME, Silva VM, Moi GP, Pignati WA, Mattos IE, Silva AMC. Parenteral exposure to pesticides and occurence of congenital malformations: hospital-based case-control study. BMC Pediatr. 2016;16:125.

355. Vallaster MP, Kukreja S, Bing XY, Ngolab J, Zhao-Shea RB, Gardner PD, Tapper AR, Rando OJ. Paternal nicotine exposure alters hepatic xenobiotic metabolism in offspring. Elife. 2017;6:e24771.

356. Valtonen TM, Kangassalo K, Pölkki M, Rantala MJ. Transgenerational effects of parental larval diet on offspring development time, adult body size and pathogen resistance in Drosophila melanogaster. PLoS One. 2012;7(2):e31611.

357. van Steenwyk G, Roszkowski M, Manuella F, Franklin TB, Mansuy IM. Transgenerational inheritance of behavioral and metabolic effects of paternal exposure to traumatic stress in early postnatal life: evidence in the 4th generation. Environ Epigenetics. 2018;4(2):dvy023.

358. Varga S, Soulsbury CD. Paternal arbuscular mycorrhizal fungal status affects DNA methylation in seeds. Biol Lett. 2017;13:20170407.

359. Varga S, Vega-Frutis R, Kytöviita MM. Transgenerational effects of plant sex and arbuscular mycorrhizal symbiosis. New Phytol. 2013;199(3):812-21.

360. Vassoler FM, White SL, Schmidt HD, Sadri-Vakili G, Christopher Pierce R. Epigenetic inheritance of a cocaine-resistance phenotype. Nat Neurosci. 2013;16(1):42-7.

361. Veenendaal MVE, Painter RC, De Rooij SR, Bossuyt PMM, Van Der Post JAM, Gluckman PD, Hanson MA, Roseboom TJ. Transgenerational effects of prenatal exposure to the 1944-45 Dutch famine. BJOG. 2013;120(5):548-53.

362. Vega-Trejo R, Kruuk LEB, Jennions MD, Head ML. What happens to offspring when parents are inbred, old or had a poor start in life? Evidence for sexspecific parental effects. J Evol Biol. 2018;31(8):1138-51.
363. Veretinskaya AG, Vekshina NL, Stanishevskaya AV, Shamakina IY, Tomilin VA, Nikolaeva W, Anokhina IP, Kuznetsova MN. Behavior and the catecholamine system of the brain in two generations of the descendants of male rats with chronic alcohol intoxication. Neurochem J. 2013;7(2):135-8.

364. Viktorin A, Levine SZ, Altemus M, Reichenberg A, Sandin S. Paternal use of antidepressants and offspring outcomes in Sweden: nationwide prospective cohort study. BMJ (Online). 2018;361:k2233.

365. Wallenius M, Lie E, Daltveit AK, Salvesen KA, Skomsvoll JF, Kalstad S, Lexberg AS, Mikkelsen K, Kvien TK, Ostensen M. No excess risks in offspring with paternal preconception exposure to disease-modifying antirheumatic drugs. Arthritis Rheumatol. 2015;67(1):296-301.

366. Wang S, Tan XL, Michaud JP, Shi ZK, Zhang F. Sexual selection drives the evolution of limb regeneration in Harmonia axyridis (Coleoptera: Coccinellidae). Bull Entomol Res. 2015;105(2):245-52.

367. Warner DA, Uller T, Shine R. Transgenerational sex determination: the embryonic environment experienced by a male affects offspring sex ratio. Sci Rep. 2013;3:2709.

368. Watkins AJ, Sinclair KD. Paternal low protein diet affects adult offspring cardiovascular and metabolic function in mice. Am J Physiol Heart Circ Physiol. 2014;306(10):H1444-52.

369. Watkins AJ, Sirovica S, Stokes B, Isaacs M, Addison O, Martin RA. Paternal low protein diet programs preimplantation embryo gene expression, fetal growth and skeletal development in mice. Biochim Biophys Acta Mol basis Dis. 2017;1863(6):1371-81.

370. Watson MJO, Hoffmann AA. Cross-generation effects for cold resistance in tropical populations of Drosophila-melanogaster and Drosophila-simulans. Austr J Zool. 1995;43(1):51-8.

371. Weselak M, Arbuckle TE, Wigle DT, Walker MC, Krewski D. Pre- and postconception pesticide exposure and the risk of birth defects in an Ontario farm population. Reprod Toxicol. 2008;25(4):472-80.

372. Weyrich A, Benz S, Karl S, Jeschek M, Jewgenow K, Fickel J. Paternal heat exposure causes DNA methylation and gene expression changes of Stat3 in wild guinea pig sons. Ecol Evol. 2016;6(9):2657-66.

373. Weyrich A, Jeschek M, Schrapers KT, Lenz D, Chung TH, Rubensam K, Yasar S, Schneemann M, Ortmann S, Jewgenow K, et al. Diet changes alter paternally inherited epigenetic pattern in male wild guinea pigs. Environ Epigenetics. 2018;4(2):dvy011

374. Weyrich A, Lenz D, Fickel J. Environmental change-dependent inherited epigenetic response. Genes. 2019;10(1):4.

375. Weyrich A, Lenz D, Jeschek M, Chung TH, Rübensam K, Göritz F, Jewgenow $\mathrm{K}$, Fickel J. Paternal intergenerational epigenetic response to heat exposure in male wild guinea pigs. Mol Ecol. 2016;25(8):1729-40.

376. White SL, Vassoler FM, Schmidt HD, Pierce RC, Wimmer ME. Enhanced anxiety in the male offspring of sires that self-administered cocaine. Addict Biol. 2016;21(4):802-10.

377. Wimmer ME, Bri LA, Fant B, Guercio LA, Arreola AC, Schmidt HD, Sidoli S, Han Y, Garcia BA, et al. Paternal cocaine taking elicits epigenetic remodeling and memory deficits in male progeny. Mol Psychiatry. 2017;22(11):1641-50.

378. Wimmer ME, Vassoler FM, White SL, Schmidt HD, Sidoli S, Han Y, Garcia BA, Pierce RC. Impaired cocaine-induced behavioral plasticity in the male offspring of cocaine-experienced sires. Eur J Neurosc. 2019;49(9):1115-1126.

379. Windham GC, Fenster L, Swan SH. Moderate maternal and paternal alcohol consumption and the risk of spontaneous abortion. Epidemiology. 1992;3(4):364-70.

380. Wu L, Lu Y, Jiao Y, Liu B, Li S, Li Y, Xing F, Chen D, Liu X, Zhao J, et al. Paternal psychological stress reprograms hepatic gluconeogenesis in offspring. Cell Metab. 2016;23(4):735-43.

381. Xia D, Parvizi N, Zhou Y, Xu K, Jiang H, Li R, Hang Y, Lu Y. Paternal fenvalerate exposure influences reproductive functions in the offspring. Reprod Sci. 2013;20(11):1308-15.

382. Xia RL, Jin LM, Li DK, Liang H, Yang F, Chen JP, Yuan W, Miao MH. Association between paternal alcohol consumption before conception and anogenital distance of offspring. Alcohol Clin Exp Res. 2018;42(4):735-42.

383. Xie K, Ryan DP, Pearson BL, Henzel KS, Neff F, Vidal RO, Hennion M, Lehmann I, Schleif M, Schröder S, et al. Epigenetic alterations in longevity regulators, reduced life span, and exacerbated aging-related pathology in old father offspring mice. Proc Natl Acad Sci U S A. 2018; 115(10):E2348-57.

384. Yang F, Chen J, Miao MH, Yuan W, Li L, Liang H, Ehrenstein V, Li J. Risk of autism spectrum disorder in offspring following paternal use of selective serotonin reuptake inhibitors before conception: a population-based cohort study. BMJ Open. 2017;7(12):e016368. 
385. Yang F, Liang H, Chen J, Miao M, Yuan W, Nørgaard M, Li J. Prenatal paternal selective serotonin reuptake inhibitors use and risk of ADHD in offspring. Pediatrics. 2018;141(1):e20171081.

386. Yang F, Yuan W, Liang H, Song X, Yu Y, Gelaye B, Miao M, Li J. Preconceptional paternal antiepileptic drugs use and risk of congenital anomalies in offspring: a nationwide cohort study. Eur J Epidemiol. 2019; 141(1):e20171081.

387. Yang MJ, Lang HY, Miao X, Liu HQ, Zhang YJ, Wang YF, Chen YB, Liu JY, Zeng $L H$, Guo GZ. Effects of paternal electromagnetic pulse exposure on the reproductive endocrine function of male offspring: a pilot study. Toxicol Res. 2018;7(6):1120-7.

388. Yaw AM, Woodruff RW, Prosser RA, Glass JD. Paternal cocaine disrupts offspring circadian clock function in a sex-dependent manner in mice. Neuroscience. 2018;379:257-68.

389. Yehuda R, Daskalakis NP, Lehrner A, Desarnaud F, Bader HN, Makotkine I, Flory JD, Bierer LM, Meaney MJ. Influences of maternal and paternal PTSD on epigenetic regulation of the glucocorticoid receptor gene in Holocaust survivor offspring. Am J Psychiatr. 2014;171(8):872-80.

390. Yeshurun S, Rogers J, Short AK, Renoir T, Pang TY, Hannan AJ. Elevated paternal glucocorticoid exposure modifies memory retention in female offspring. Psychoneuroendocrinology. 2017;83:9-18.

391. Ying Y, Chow PH, O.W.S. Effects of male accessory sex glands on deoxyribonucleic acid synthesis in the first cell cycle of golden hamster embryos. Biol Reprod. 1998;58(3):659-63.

392. Youngstein T, Hoffmann P, Gul A, Lane T, Williams R, Rowczenio DM, Ozdogan H, Ugurlu S, Ryan J, Harty L, et al. International multi-centre study of pregnancy outcomes with interleukin-1 inhibitors. Rheumatology. 2017; 56(12):2102-8

393. Yu M, Guo L, Li N, Henzel KS, Gu H, Ran X, Sun W, Liu S, Lu Y, Ehninger D, et al. Overexpression of Kcnmb2 in dorsal CA1 of offspring mice rescues hippocampal dysfunction caused by a methyl donor-rich paternal diet. Front Cell Neurosci. 2018;12:360.

394. Zajitschek F, Zajitschek S, Manier M. High-protein paternal diet confers an advantage to sons in sperm competition. Biol Lett. 2017;13(2):20160914.

395. Zajitschek S, Herbert-Read JE, Abbasi NM, Zajitschek F, Immler S. Paternal personality and social status influence offspring activity in zebrafish. BMC Evol Biol. 2017;17:157.

396. Zajitschek S, Hotzy C, Zajitschek F, Immler S. Short-term variation in sperm competition causes sperm-mediated epigenetic effects on early offspring performance in the zebrafish. Proc R Soc B Biol Sci. 2014;281:20140422.

397. Zanchi C, Troussard JP, Martinaud G, Moreau J, Moret Y. Differential expression and costs between maternally and paternally derived immune priming for offspring in an insect. J Anim Ecol. 2011;80(6):1174-83.

398. Zeh JA, Bonilla MM, Adrian AJ, Mesfin S, Zeh DW. From father to son: transgenerational effect of tetracycline on sperm viability. Sci Rep. 2012;2: 375.

399. Zhang GL, Zhang XF, Feng YM, Li L, Huynh E, Sun XF, Sun ZY, Shen W. Exposure to bisphenol $A$ results in a decline in mouse spermatogenesis. Reprod Fertil Dev. 2013;25(6):847-59.

400. Zhang X, Dong Y, Sun G, Hasan AA, Tian M, Zeng S, Li J, Zeng S, Ma J, Li J, et al. Paternal programming of liver function and lipid profile induced by a paternal pre-conceptional unhealthy diet: potential association with altered gut microbiome composition. Kidney Blood Press Res. 2019:133-48.

401. Zhao C, Zhang LS, Shi DT, Ding JY, Yin DH, Sun JN, Zhang BJ, Zhang LL, Chang YQ. Transgenerational effects of ocean warming on the sea urchin Strongylocentrotus intermedius. Ecotoxicol Environ Saf. 2018;151:212.

402. Zhao XG, Cheng ZZ, Zhu Y, Li S, Zhang L, Luo YB. Effects of paternal cadmium exposure on the sperm quality of male rats and the neurobehavioral system of their offspring. Exp Ther Med. 2015;10(6):2356-60.

403. Zhou Y, Zhu H, Wu HY, Jin LY, Chen B, Pang HY, Ming ZH, Cheng Y, Zhou $\mathrm{CL}$, Guo MX, et al. Diet-induced paternal obesity impairs cognitive function in offspring by mediating epigenetic modifications in spermatozoa. Obesity. 2018;26(11):1749-57

404. Zhu B, Maddocks S. The effect of paternal heat stress on protein profiles of pre-implantation embryos in the mouse. Int J Androl. 2005;28(3):128-36.

405. Adams PM. Evaluation of the effects of paternal drug/chemical exposure on the offspring. Congenit Anom. 1987;27(2):103-10.

406. Anderson D. Overview of male-mediated developmental toxicity. In: Robaire B., Hales B.F. (eds) Advances in Male Mediated Developmental Toxicity. Advances in Experimental Medicine and Biology, vol 518. Springer, Boston, MA. 2003;518:11-24
407. Auroux M. Long-term effects in progeny of paternal environment and of gamete/embryo cryopreservation. Hum Reprod Update. 2000;6(6):550-63.

408. Baber M, Koren G. Investigating the fetal and postnatal effects of paternal alcohol exposure in mouse offspring: a review. J Popul Ther Clin Pharmacol. 2015;22(1):e57-8.

409. Bale TL. Lifetime stress experience: transgenerational epigenetics and germ cell programming. Dialogues Clin Neurosci. 2014;16(3):297-305.

410. Baskin JM, Baskin CC. How much influence does the paternal parent have on seed germination? Seed Sci Res. 2019;29(1):1-11.

411. Becker C. Paternal effects: like father, like son. Elife. 2017;6:e25669.

412. Bernal AJ, Murphy SK, Jirtle RL: Mouse models of epigenetic inheritance. In: Editor(s): Trygve Tollefsbol, Handbook of Epigenetics, Academic Press, 2011: 233-249.

413. Bohacek J, Weber-Stadlbauer U, Mansuy IM. Paternal experience impacts cognitive function in offspring: a pre-existing concept. Mol Psychiatry. 2018; 23(4):794-5

414. Bonduriansky R, Crean AJ. What are parental condition-transfer effects and how can they be detected? Methods Ecol Evol. 2018;9(3):450-6.

415. Cerf ME. Parental high-fat programming of offspring development, health and beta-cells. Islets. 2011;3(3):118-20

416. Chan D, Trasler J, Zini A, Agarwal A. The sperm epigenome; 2011.

417. Chan JC, Nugent BM, Bale TL. Parental advisory: maternal and paternal stress can impact offspring neurodevelopment. Biol Psychiatry. 2018;83(10):886-94.

418. Chapin RE, Robbins WA, Schieve LA, Sweeney AM, Tabacova SA, Tomashek KM. Off to a good start: the influence of pre- and periconceptional exposures, parental fertility, and nutrition on children's health. Environ Health Perspect. 2004;112(1):69-78.

419. Cheng PJ, Pastuszak AW, Hotaling JM. Is it time to start folate supplementation in men? The effect of paternal folate status on embryonic growth. Fertil Steril. 2019;111(2):251-2.

420. Cordier S. Evidence for a role of paternal exposures in developmental toxicity. Basic Clin Pharmacol Toxicol. 2008;102(2):176-81.

421. Curley JP, Mashoodh R. Parent-of-origin and trans-generational germline influences on behavioral development: the interacting roles of mothers, fathers, and grandparents. Dev Psychobiol. 2010;52(4):312-30.

422. Curley JP, Mashoodh R, Champagne FA, Tollefsbol T. Transgenerational epigenetics; 2011.

423. Davis DL, Friedler G, Mattison D, Morris R. Male-mediated teratogenesis and other reproductive effects: biologic and epidemiologic findings and a plea for clinical research. Reprod Toxicol. 1992;6(4):289-92.

424. Day J, Savani S, Krempley BD, Nguyen M, Kitlinska JB. Influence of paternal preconception exposures on their offspring: through epigenetics to phenotype. Am J Stem Cells. 2016;5(1):11-8.

425. Desai M, Jellyman JK, Ross MG. Epigenomics, gestational programming and risk of metabolic syndrome. Int J Obes. 2015;39(4):633-41.

426. Dunford AR, Sangster JM. Maternal and paternal periconceptional nutrition as an indicator of offspring metabolic syndrome risk in later life through epigenetic imprinting: a systematic review. Diab Metab Syndr Clin Res Rev. 2017;11:S655-62.

427. Eisenberg DTA, Kuzawa CW. The paternal age at conception effect on offspring telomere length: mechanistic, comparative and adaptive perspectives. Philos Trans R Soc B Biol Sci. 2018;373:20160442.

428. Ferguson-Smith AC, Patti ME. You are what your dad ate. Cell Metab. 2011; 13(2):115-7

429. Finegersh A, Rompala GR, Martin DIK, Homanics GE. Drinking beyond a lifetime: new and emerging insights into paternal alcohol exposure on subsequent generations. Alcohol. 2015:49(5):461-70.

430. Fontelles CC, da Cruz RS, Hilakivi-Clarke L, de Assis S, Ong TP. Investigation of paternal programming of breast cancer risk in female offspring in rodent models. Methods Mol Biol. 2018;1735:207-20.

431. Fontelles CC, da Cruz RS, Hilakivi-Clarke L, de Assis S, Ong TP. Developmental origins of breast cancer: a paternal perspective. In: Guest $P$. (eds) Investigations of Early Nutrition Effects on Long-Term Health. Methods in Molecular Biology, vol 1735. Humana Press, New York, NY. 2018;1735:91103.

432. Friedler G. Paternal exposures: impact on reproductive and developmental outcome. An overview. Pharmacol Biochem Behav. 1996;55(4):691-700.

433. Gapp K, Miska EA. TRNA fragments: novel players in intergenerational inheritance. Cell Res. 2016;26(4):395-6.

434. Geiger JM, Walker M, et al. Dermatology (Basel, Switzerland). 2002;205(2): $105-7$. 
435. Goldberg LR, Gould TJ. Multigenerational and transgenerational effects of paternal exposure to drugs of abuse on behavioral and neural function. Eur J Neurosci. 2019;50(3):2453-2466.

436. Gottesfeld Z, Abel EL. Maternal and paternal alcohol use: effects on the immune system of the offspring. Life Sci. 1991;48(1):1-8.

437. Hales BF, Robaire B. Paternal exposure to drugs and environmental chemicals: effects on progeny outcome. J Androl. 2001;22(6):927-36.

438. Hales BF, Robaire B. The male germ cell as a target for toxicants. In: McQueen CA, ed. Comprehensive Toxicology Kidlington, United Kingdom Elsevier Ltd 2010:115-29.

439. Hannan AJ. Stressing the seminal role of paternal experience in transgenerational 'epigenopathy' affecting offspring health and disease susceptibility. Neuroscience. 2018;388:472-3.

440. Hine C. A paternal diet for offspring success? Sci Transl Med. 2017;9(386): eaan2780.

441. Holland ML, Rakyan VK. Transgenerational inheritance of non-genetically determined phenotypes. Biochem Soc Trans. 2013:41(3):769-76.

442. Hwang K, Gittens P, Avila D, Jr., Lipshultz LI: Impact of paternal exposure to gonadotoxins on embryo and offspring and the male evaluation. In: Seli E, Agarwal A. (eds) Fertility Preservation. Springer, New York, NY. 2012: 271-288.

443. Illum LRH, Bak ST, Lund S, Nielsen AL. DNA methylation in epigenetic inheritance of metabolic diseases through the male germ line. J Mol Endocrinol. 2018;60(2):R39-56.

444. Immler S. The sperm factor: paternal impact beyond genes. Heredity. 2018; 121(3):239-47.

445. Isganaitis E, Suehiro H, Cardona C. Who's your daddy?: paternal inheritance of metabolic disease risk. Curr Opin Endocrinol Diab Obes. 2017:24(1):47-55.

446. James WH. Offspring sex ratios at birth as markers of paternal endocrine disruption. Environ Res. 2006;100(1):77-85.

447. James $\mathbf{W H}$. The offspring sex ratios of male mammals treated with dioxin before mating: comment on the paper of Ishihara et al. Reprod Toxicol. 2010;29(2):246.

448. Jenkins TG, Aston Kl, Meyer T, Carrell DT. The sperm epigenome, male aging, and potential effects on the embryo. Adv Exp Med Biol. 2015;868:8193.

449. Jenkins TG, Carrell DT. The sperm epigenome and potential implications for the developing embryo. Reproduction. 2012;143(6):727-34.

450. Kaati G: Case studies on epigenetic inheritance. In: Epigenetics and Human Health, A.G. Haslberger (Ed.). 2010: 63-86.

451. Karalexi MA, Dessypris N, Thomopoulos TP, Ntouvelis E, Kantzanou M, Diamantaras AA, Moschovi M, Baka M, Hatzipantelis E, Kourti M, et al. Parental alcohol consumption and risk of leukemia in the offspring: a systematic review and meta-analysis. Eur J Cancer Prev. 2017;26(5): 433-41.

452. Kashem MA, Lee A, Pow DV, Šerý O, Balcar VJ. Could ethanol-induced alterations in the expression of glutamate transporters in testes contribute to the effect of paternal drinking on the risk of abnormalities in the offspring? Med Hypotheses. 2017;98:57-9.

453. Kimmins S. Expanding waistlines heighten the risk for reproductive toxicity. Biol Reprod. 2010;82(1):1-3

454. Klastrup LK, Bak ST, Nielsen AL. The influence of paternal diet on sncRNAmediated epigenetic inheritance. Mol Gen Genomics. 2019;294(1):1-11.

455. Kumar M, Kumar K, Jain S, Hassan T, Dada R. Novel insights into the genetic and epigenetic paternal contribution to the human embryo. Clinics. 2013; 68:5-14.

456. Kumar P, Das A, Lal NR, Jain S, Ghosh A. Safety of important dermatological drugs (retinoids, immune suppressants, anti androgens and thalidomide) in reproductively active males with respect to pregnancy outcome: a brief review of literature. Ind J Dermatol Venereol Leprol. 2018;84(5): 539-46.

457. Li J, Tsuprykov O, Yang X, Hocher B. Paternal programming of offspring cardiometabolic diseases in later life. J Hypertens. 2016;34(11):2111-26.

458. Liu YS. Telegony, the sire effect and non-Mendelian inheritance mediated by spermatozoa: a historical overview and modern mechanistic speculations. Reprod Domest Anim. 2011;46(2):338-43.

459. Loche E, Ozanne SE. Non-genetic transmission of obesity - it's in your epigenes. Trends Endocrinol Metab. 2016;27(6):349-50.

460. Lucas ES, Watkins AJ, Fazeli A, Holt W. The long-term effects of the periconceptional period on embryo epigenetic profile and phenotype; the paternal role and his contribution, and how males can affect offspring's phenotype/epigenetic profile. Adv Exp Med Biol. 2017;1014:137-54.
461. Ly L, Chan D, Trasler JM. Developmental windows of susceptibility for epigenetic inheritance through the male germline. Semin Cell Dev Biol. 2015;43:96-105

462. Macartney EL, Crean AJ, Bonduriansky R. Epigenetic paternal effects as costly, condition-dependent traits. Heredity. 2018;121(3):248-56.

463. Manson JM. Human and laboratory animal test systems available for detection of reproductive failure. Prev Med. 1978;7(3):322-31.

464. Mansuy IM, Mashoodh R, Champagne FA, Sweatt JD, Meaney MJ, Nestler EJ, Akbarian S. Transgenerational inheritance in mammals; 2013.

465. Marshall DJ. Environmentally induced (co)variance in sperm and offspring phenotypes as a source of epigenetic effects. J Exp Biol. 2015; 218(1):107-13.

466. McGowan PO, Matthews SG. Prenatal stress, glucocorticoids, and developmental programming of the stress response. Endocrinology. 2018; 159(1):69-82.

467. Micu MC, Ostensen M, Villiger PM, Micu R, lonescu R. Paternal exposure to antirheumatic drugs-what physicians should know: review of the literature. Semin Arthritis Rheum. 2018;48(2):343-55.

468. Morgan $C P$, Chan JC, Bale TL. Driving the next generation: paternal lifetime experiences transmitted via extracellular vesicles and their small RNA cargo. Biol Psychiatry. 2019;85(2):164-71

469. Murphy KE, Jenkins TG, Carrell DT: How the father might epigenetically program the risk for developmental origins of health and disease effects in his offspring. In: Editor(s): Cheryl S. Rosenfeld, The Epigenome and Developmental Origins of Health and Disease, Academic Press. 2015: 361-375.

470. Murphy KE, Murphy PJ, Carrell DT: Epigenetic changes in the paternal germline. In: Editor(s): Trygve Tollefsbol, Transgenerational Epigenetics, Academic Press. 2014: 43-55.

471. Nagao T, Takada N, Onoda N. Transgenerational teratogenesis by prenatal exposure to endocrine disrupting chemicals. Genes Environ. 2011;33(2):50-60.

472. Nanassy L, Carrell DT. Paternal effects on early embryogenesis. J Exp Clin Assist Reprod. 2008:5:2.

473. Nelson BK, Moorman WJ, Schrader SM. Review of experimental malemediated behavioral and neurochemical disorders. Neurotoxicol Teratol. 1996;18(6):611-6.

474. Nieto SJ, Patriquin MA, Nielsen DA, Kosten TA. Don't worry; be informed about the epigenetics of anxiety. Pharmacol Biochem Behav. 2016:146:60-72.

475. Oliveira PF, Sousa M, Sliva BM, Monteiro MP, Alves MG. Obesity, energy balance and spermatogenesis. Reproduction. 2017;153(6):R173-85.

476. Pacchierotti F, Spano M. Environmental impact on DNA methylation in the germline: state of the art and gaps of knowledge. Biomed Res Int. 2015; Article ID 123484:23 pages.

477. Pang TY, Short AK, Bredy TW, Hannan AJ. Transgenerational paternal transmission of acquired traits: stress-induced modification of the sperm regulatory transcriptome and offspring phenotypes. Curr Opin Behav Sci. 2017;14:140-7.

478. Pearson BL, Ehninger D. Impact of paternal nutrition on epigenetic patterns. Epigenomics. 2018;10(2):115-7

479. Perrin M, Kleinhaus K, Opler M, Messinger J, Malaspina D: Epidemiology research and epigenetics: translational epidemiology of schizophrenia. In: A. Petronis and J. Mill (eds.), Brain, Behavior and Epigenetics, Epigenetics and Human Health, Springer-Verlag Berlin Heidelberg. 2011:71-96.

480. Portha B, Grandjean V, Movassat J. Mother or father: who is in the front line? Mechanisms underlying the non-genomic transmission of obesity/ diabetes via the maternal or the paternal line. Nutrients. 2019;11(2):233.

481. Puri D, Dhawan J, Mishra RK. The paternal hidden agenda: epigenetic inheritance through sperm chromatin. Epigenetics. 2010;5(5):386-91.

482. Robaire B, Codrington AM, Hales BF, Anderson D, Brinkworth MH: Molecular changes in sperm and early embryos after paternal exposure to a chemotherapeutic agent. In 'Male-Mediated Developmental Toxicity'. (Ed D. Anderson.), RSC Publishing. 2007: 124-133.

483. Robaire B, Hales BF. Paternal exposure to chemicals before conception. Br Med J. 1993;307(6900):341-2

484. Rodgers AB, Bale TL. Germ cell origins of posttraumatic stress disorder risk the transgenerational impact of parental stress experience. Biol Psychiatry. 2015:78(5):307-14

485. Romanus S, Neven P, Soubry A. Extending the developmental origins of health and disease theory: does paternal diet contribute to breast cancer risk in daughters? Breast Cancer Res. 2016;18(1):103.

486. Rorije E, Muller A, Beekhuijzen MEW, Hass U, Heinrich-Hirsch B, Paparella M, Schenk E, Ulbrich B, Hakkert BC, Piersma AH. On the impact of second 
generation mating and offspring in multi-generation reproductive toxicity studies on classification and labelling of substances in Europe. Regul Toxicol Pharmacol. 2011;61(2):251-60.

487. Rowold ED, Schulze L, Van der Auwera S, Grabe HJ. Paternal transmission of early life traumatization through epigenetics: do fathers play a role? Med Hypotheses. 2017:109:59-64.

488. Pierce RC, Vassoler FM. Reduced cocaine reinforcement in the male offspring of cocaine-experienced sires. Neuropsychopharmacology. 2014; 39(1):238.

489. McLain VC. Final report of the addendum to the safety assessment of $n$ butyl alcohol as used in cosmetics. Int J Toxicol. 2008;27:53-69.

490. Sands K, Jansen R, Zaslau S, Greenwald D. Review article: the safety of therapeutic drugs in male inflammatory bowel disease patients wishing to conceive. Aliment Pharmacol Ther. 2015;41(9):821-34.

491. Sarkar DK. Male germline transmits fetal alcohol epigenetic marks for multiple generations: a review. Addict Biol. 2016;21(1):23-34.

492. Savitz DA, Chen J. Parental occupation and childhood cancer: review of epidemiologic studies. Environ Health Perspect. 1990;88:325-37.

493. Schagdarsurengin $U$, Steger K. Epigenetics in male reproduction: effect of paternal diet on sperm quality and offspring health. Nat Rev Urol. 2016; 13(10):584-95.

494. Schagdarsurengin U, Western P, Steger K, Meinhardt A. Developmental origins of male subfertility: role of infection, inflammation, and environmental factors. Semin Immunopathol. 2016;38(6):765-81.

495. Schubert C. Blame it on papa: paternal effects of diet. Biol Reprod. 2013; 89(5):106, 1-3.

496. Scofield MD, Kalivas PW. Forgiving the sins of the fathers. Nat Neurosci. 2013;16(1):4-5

497. Shah PS. Paternal factors and low birthweight, preterm, and small for gestational age births: a systematic review. Am J Obstet Gynecol. 2010; 202(2):103-23.

498. Sharma R, Agarwal A, Rohra VK, Assidi M, Abu-Elmagd M, Turki RF. Effects of increased paternal age on sperm quality, reproductive outcome and associated epigenetic risks to offspring. Reprod Biol Endocrinol. 2015;13:35

499. Sharp GC, Lawlor DA, Richardson SS. It's the mother!: how assumptions about the causal primacy of maternal effects influence research on the developmental origins of health and disease. Soc Sci Med. 2018;213:20-7.

500. Siddeek B, Mauduit C, Simeoni U, Benahmed M. Sperm epigenome as a marker of environmental exposure and lifestyle, at the origin of diseases inheritance. Mutat Res Rev Mutat Res. 2018;778:38-44.

501. Slyvka Y, Zhang Y, Nowak FV. Epigenetic effects of paternal diet on offspring: emphasis on obesity. Endocrine. 2014;48(1):36-46.

502. Soubry A. POHaD: why we should study future fathers. Environ Epigenetics. 2018;4(2):dvy007

503. Soubry A, Hoyo C, Jirtle RL, Murphy SK. A paternal environmental legacy: evidence for epigenetic inheritance through the male germ line. BioEssays. 2014;36(4):359-71.

504. Spagnolo A. Teratogenesis of alcohol. Ann Ist Super Sanita. 1993;29(1):89-96.

505. Stuppia L, Franzago M, Ballerini P, Gatta V, Antonucci I. Epigenetics and male reproduction: the consequences of paternal lifestyle on fertility, embryo development, and children lifetime health. Clin Epigenetics. 2015;7:120.

506. Taskinen HK. Effects of parental occupational exposures on spontaneous abortion and congenital malformation. Scand J Work Environ Health. 1990; 16(5):297-314

507. Terrell ML, Hartnett KP, Marcus M. Can environmental or occupational hazards alter the sex ratio at birth? A systematic review. Emerg Health Threats J. 2011:4(1):7109.

508. Tunc-Ozcan E, Sittig LJ, Harper KM, Graf EN, Redei EE. Hypothesis: genetic and epigenetic risk factors interact to modulate vulnerability and resilience to FASD. Front Genet. 2014;5:261.

509. Vanhees K, Vonhogen IGC, van Schooten FJ, Godschalk RWL. You are what you eat, and so are your children: the impact of micronutrients on the epigenetic programming of offspring. Cell Mol Life Sci. 2014;71(2):271-85.

510. Vaughn AR, Sivamani RK, Lio PA, Shi VY. Paternal vs. maternal factors in childhood atopic dermatitis. Dermatitis. 2017:28(4):241-5.

511. Whalley K. Epigenetics: from father to son. Nat Rev Neurosci. 2011; 12(10):548.

512. Wigle DT, Turner MC, Krewski D. A systematic review and meta-analysis of childhood leukemia and parental occupational pesticide exposure. Environ Health Perspect. 2009;117(10):1505-13.
513. Woestmann L, Saastamoinen M. The importance of trans-generational effects in lepidoptera. Curr Zool. 2016;62(5):489-99.

514. Yan MH, Zhai QW. Sperm tsRNAs and acquired metabolic disorders. J Endocrinol. 2016;230(3):F13-8.

515. Yeshurun S, Hannan AJ. Transgenerational epigenetic influences of paternal environmental exposures on brain function and predisposition to psychiatric disorders. Mol Psychiatry. 2019;24(4):536-548.

516. Youngson NA, Whitelaw E. The effects of acquired paternal obesity on the next generation. Asian J Androl. 2011;13(2):195-6.

517. Zamudio NM, Chong SY, O'Bryan MK. Epigenetic regulation in male germ cells. Reproduction. 2008;136(2):131-46.

518. Zeisel $\mathrm{SH}$. Epigenetic mechanisms for nutrition determinants of later health outcomes. Am J Clin Nutr. 2009;89(5):1488S-93S.

519. Core Team R. R: a language and environment for statistical computing. Vienna: R Foundation for Statistical Computing; 2020.

520. Wickham H. Ggplot2: elegant graphics for data analysis; 2009.

521. Aria M, Cuccurullo C. bibliometrix: an R-tool for comprehensive science mapping analysis. J Informetrics. 2017;11(4):959-75.

522. Nettle D, Frankenhuis WE. The evolution of life-history theory: a bibliometric analysis of an interdisciplinary research area. Proc R Soc B Biol Sci. 2019; 286(1899):20190040

\section{Publisher's Note}

Springer Nature remains neutral with regard to jurisdictional claims in published maps and institutional affiliations.
Ready to submit your research? Choose BMC and benefit from:

- fast, convenient online submission

- thorough peer review by experienced researchers in your field

- rapid publication on acceptance

- support for research data, including large and complex data types

- gold Open Access which fosters wider collaboration and increased citations

- maximum visibility for your research: over $100 \mathrm{M}$ website views per year

At BMC, research is always in progress.

Learn more biomedcentral.com/submissions 